\title{
The impact of labor market entry conditions on initial job assignment and wages
}

\author{
Beatrice Brunner • Andreas Kuhn
}

Received: 23 February 2012 / Accepted: 25 September 2013 /

Published online: 25 October 2013

(C) Springer-Verlag Berlin Heidelberg 2013

\begin{abstract}
We estimate the effects of labor market entry conditions on wages for male individuals first entering the Austrian labor market between 1978 and 2000. We find a large negative effect of unfavorable entry conditions on starting wages and a sizable negative long-run effect. Our preferred estimates imply a decrease in starting wages by about $0.9 \%$ and a lifetime loss in wages of about $1.3 \%$ for an increase in the initial local unemployment rate by one percentage point. We show that poor entry conditions are associated with lower quality of a worker's first employer and that the quality of workers' first employer explains as much as three-quarters of the observed long-run wage effects resulting from poor entry conditions. Moreover, wage effects are much more persistent for blue-collar workers because some of them appear to be permanently locked in into low-paying jobs/tasks.
\end{abstract}

Keywords Initial labor market conditions · Endogenous labor market entry · Initial job assignment

Responsible editor: Junsen Zhang

Electronic supplementary material The online version of this article (doi:10.1007/s00148-013-0494-4) contains supplementary material, which is available to authorized users.

B. Brunner

ZHAW Zurich University of Applied Sciences, Gertrudstrasse 15, 8401 Winterthur, Switzerland

A. Kuhn ( $\triangle)$

Swiss Federal Institute for Vocational Education and Training, Kirchlindachstrasse 79, 3052 Zollikofen, Switzerland

e-mail: andreas.kuhn@econ.uzh.ch

B. Brunner · A. Kuhn

Department of Economics, University of Zurich, Zurich, Switzerland

A. Kuhn

IZA, Bonn, Germany 
JEL Classifications E32 $\cdot$ J31 J J62

\section{Introduction}

The recent economic crisis has renewed academic interest in the potential impact of business cycle fluctuations on labor markets (e.g., Elsby et al. 2010). However, while labor economists have studied on the short-run association between local labor market conditions and real wages extensively for quite some time (e.g., Blanchflower and Oswald 1990), longer-run effects of business cycle fluctuations on individual's wages have only more recently caught the attention of empirical research. ${ }^{1}$ Clearly, even small initial wage shortfalls may, in the longer run, eventually accrue to substantial overall losses in lifetime earnings if initial wage losses resulting from poor entry conditions persist. ${ }^{2}$

Indeed, recent empirical evidence suggests that substantial losses in lifetime earnings result from entering the labor market during an economic downturn, as opposed to entering during an expansion. ${ }^{3}$ Oreopoulos et al. (2012) explore the effects of entering the labor market during a recession on individuals' earnings, using data on Canadian college graduates who entered the labor market between 1982 and 1999. They find a substantial initial wage penalty of about $9 \%$ that only fades to zero after the first decade of a worker's career. A similar result is reported by Kahn (2010), who focuses on male college graduates in the USA graduating sometime between 1979 and 1988. She finds that the group graduating in the worst economic situation incurs a wage loss of up to $13 \%$ each year, relative to those graduating in the best initial conditions, and that this initial wage loss persists over the first 20 years of a workers' labor market career. Similar results are reported by Oyer (2006), who shows that PhD students in economics are considerably more likely to find a position at one of the top universities in the USA if they graduate in times when the demand for economists is high. In a related study, he finds that those MBA students who complete their training during a recession suffer from negative effects on wages (Oyer 2008). In both studies, the long-term effects on income appear to stem from the fact that diverse

\footnotetext{
${ }^{1}$ Most studies estimating the short-run association between fluctuations in local unemployment rates and wages find that wages vary negatively with local unemployment. This negative association is a very robust empirical pattern; it has been shown to exist for a wide range of different countries, using very different sources of data and diverse empirical specifications. See Nijkamp and Poot (2005) for a comprehensive survey of this literature.

${ }^{2}$ Previous research has shown that the early years in a worker's labor market career are of special importance (Gardecki and Neumark 1998; Neumark 2002). In terms of wages, Murphy and Welch (1990) estimate that almost $80 \%$ of all (i.e., lifetime) wage increases accrue within the first 10 years of labor market experience. Moreover, movements across jobs are considerably more likely at the beginning of a worker's career than later on (Topel and Ward 1992).

${ }^{3}$ Various dimensions other than wages may be influenced by conditions at labor market entry. For example, Giuliano and Spilimbergo (2009) show that entry conditions have long-lasting effects on individuals' beliefs and preferences, while Kondo (2012) finds that the timing of marriage of both men and women is influenced by entry conditions.
} 
employers hire workers entering the labor market under different conditions, therefore giving them access to distinct jobs. The entry job is thus significant for the future career, and this appears to be of particular importance for highly educated individuals for whom the transition in and out of attractive positions is very low. ${ }^{4}$ Mansour (2009) also focuses on college graduates in the USA and again finds negative and persistent wage effects from entry into the labor force during a recession. Moreover, he shows that failure to account for endogenous sample composition underestimates both the immediate wage effects as well as the persistence of wage effects resulting from initial labor market shocks.

Empirical evidence for countries outside the USA and Canada yields broadly similar findings. Kwon et al. (2010) mainly use data from the Swedish labor market. ${ }^{5}$ They find that workers who enter the labor market during a boom are not only paid higher wages, but that they are also promoted more quickly to higher ranks than those who enter during an economic downturn. Stevens (2007) finds significant negative, albeit small, effects of initial conditions on wages in Germany (much smaller than those found in the USA and Canada). In contrast to all other studies, however, she finds that wage losses from poor entry conditions do not fade away, but actually increase over time. ${ }^{6}$ The available empirical evidence also underlines the fact that negative wage effects of initial labor market conditions are not confined to highly skilled workers. Genda et al. (2010) focus on a separate comparison between men in Japan and the USA with more or less education with respect to the effects of initial conditions. They find negative effects of initial conditions for more highly skilled workers in both countries. However, they only find negative wage effects for workers in Japan with fewer skills. They argue that the specific hiring system and employment protection drive the persistence of the effects for Japanese, while the market for less-skilled workers in the USA may indeed be quite close to a competitive market. Consistent with this finding, Kondo (2008) reports that the initial effect of entering the labor market during a recession on wages is less persistent for less-skilled workers and for workers with weak labor market attachment in the USA.

\footnotetext{
${ }^{4}$ One important concern regarding the validity of these results is that schooling and first entry into the labor force may be endogenous both because individuals may choose to stay in school or continue further training when faced with high unemployment and low starting wages. Indeed, several studies find that enrollment rates are high when unemployment is high and the opportunity costs of schooling are low (Clark 2011). In line with these findings, both Kahn (2010) and Oreopoulos et al. (2012) find the duration of schooling to be endogenous. Both tackle the endogeneity problem by instrumenting the unemployment rate at the time of labor market entry with either the prevailing unemployment rate at a lower age or that in the predicted year of graduation. Mansour (2009) presents direct evidence on sample selection over the business cycle based on AFQT scores.

${ }^{5}$ Previous studies for European countries have mainly focused on the long-run effects of initial conditions on employment rather than wages (e.g., Burgess et al. 2003; Raaum and Røed 2006).

${ }^{6} \mathrm{~A}$ similar analysis of wage effects for firm entry cohorts in the German manufacturing sector is given by von Wachter and Bender (2008). However, their analysis is not confined to new labor market entrants, but covers workers of all experience levels; their results are therefore not directly comparable to the other studies mentioned.
} 
In this paper, we present estimates of the long-run effects of business cycle fluctuations on young males' wage profiles in the Austrian labor market and derive an empirical estimate of the associated loss in lifetime earnings due to entering the labor force during a recession, as opposed to entry during average aggregate conditions or during a boom. We do so using Austrian social security records that contain detailed individual earnings and employment histories for the universe of privatesector employees from 1972 until 2005. We complement the available empirical evidence on the long-run wage effects of labor market entry conditions with an analysis for Austria, a labor market characterized by a high level of employment protection and a centralized wage bargaining structure. We focus on low- and medium-skilled workers, while most of the studies mentioned above focus on higher or even highestskilled workers (in terms of formal education). ${ }^{7}$ In the second part of the analysis, we focus on changes in the quality of workers' first employer over the business cycle and the importance of first employers for individuals' entry and subsequent wages. Indeed, several previous studies have shown that workers' initial placements may have important effects not only on their entry wages but also on their subsequent wages (e.g., von Wachter and Bender 2006; Oreopoulos et al. 2012). More specifically, initial job or task assignment may be important in the longer run if employers assign otherwise identical workers to lower-quality jobs or tasks in recession, and if jobs or tasks offer different opportunities for the accrual of human capital (e.g., Gibbons and Waldman 2006). ${ }^{8}$ Alternatively, workers' initial job or task assignment may have long-lasting effects on wages if workers accumulate human capital while on the job that is not fully transferable to other jobs or tasks because it is specific to a worker's task, occupation, or industry.

The remainder of this paper is organized as follows. The next section presents our data source, details the sample selection process, and discusses the construction of our key measures. Section 3 presents the econometric approach for estimating longrun wage effects of initial labor market conditions along with our main results. We also present some robustness tests as well as some evidence on the importance of endogenous labor market entry over the business cycle. In Section 4, we focus on the impact of initial labor market conditions on the quality of workers' first employer and the importance of first employer on individuals' subsequent wages. Section 5 concludes.

\footnotetext{
${ }^{7}$ Note, however, that workers in the Austrian labor market typically have some, potentially very specialized, vocational training, as a significant part of the initial vocational training in Austria is provided by dual apprenticeship training schemes, i.e., practical training provided by firms coupled with part-time compulsory attendance at a vocational school. Apprenticeships last from 2 to 4 years, depending on occupation. Full-time vocational and technical schools provide an important alternative to apprenticeship training and also last up to 4 years. Details are available from the report by the Federal Ministry for Education, the Arts and Culture (2008).

${ }^{8}$ Consistent with this line of argument, Kwon et al. (2010) find that workers who enter the labor market during a boom are promoted more quickly and to higher ranks than those who enter during a recession, and Mansour (2009) shows that workers entering in a recession are initially assigned to lowerpaying jobs.
} 


\section{Data and sample}

\subsection{Data source}

We use individual-level social security records from the Austrian Social Security Database (ASSD), a data source described in more detail by Zweimüller et al. (2009). The ASSD basically covers the universe of Austrian private sector workers from January 1972 until December 2005 and contains complete and precise information about individuals' annual earnings and daily employment histories. The data are therefore ideally suited for studying on the impact of labor market shocks on long-run wage profiles because they allow us to construct individual wage profiles for a large number of labor market entrants over a relatively long period of time.

\subsection{Key measures}

Our dependent variable for most of the analysis is the real daily wage, i.e., the real wage per actual day of work, adjusted to 2007 prices. Wages are deflated with the consumer price index and include additional/special payments such as a 13th month's salary or holiday pay. ${ }^{9}$ Real daily wages are computed as the average earnings over all employers in a given year. This means that we first sum the total annual earnings over all employers for any individual. We then divide overall earnings by the total number of days worked in a given year, also summed over all employers for a given individual and taking overlapping employment spells into account.

The regressor of main interest is the annual male unemployment rate, our measure for external labor market conditions at the time individuals first enter the labor force. We compute annual male unemployment rates from the individual-level employment histories contained in the ASSD raw data. This procedure has the advantage that we can calculate unemployment rates back until 1972 (compared to published statistics, which only reach back until 1978) and at different levels of cross-sectional aggregation. ${ }^{10}$ Unless noted otherwise, we use the male unemployment rate for all workers aged between 16 and 65 at the state level as our main regressor.

\footnotetext{
${ }^{9}$ The Austrian Central Social Security Administration collects these data with the purpose of administering and calculating entitlements to old-age pension benefits. For this reason, the ASSD includes precise and comprehensive information on annual earnings and daily employment histories. However, contributions to the old-age pension system are capped because old-age pension benefits are limited to a maximum level. As a consequence, annual earnings are only recorded up to the threshold which guarantees the maximum benefit level ("Höchstbemessungsgrundlage", HBGr). Similarly, there is a base threshold below which no (otherwise mandatory) social security payments accrue ("Geringfügigkeitsgrenze", GfGr). The two censoring points vary over time in real terms: The lower censoring point increased from about $14 €$ in 1978 to about $26 €$ in 2005 (per day worked); the upper censoring point increased from about $78 €$ to $126 €$ per workday over the same period of time.

${ }^{10}$ We decided to extract yearly male unemployment rates for the age groups 16 to 65 and 16 to 25 , both at the state ("Bundesland") level and at the common classification of territorial units for statistics (NUTS) level. At the NUTS level, we use the most disaggregated level available (NUTS-3), which corresponds to one or more political districts in Austria. There are total of nine different states and 35 different NUTS-3 regions in Austria. Yearly unemployment rates are within-year averages of monthly unemployment rates.
} 


\subsection{Sample selection}

Mainly for conceptual reasons, but also due to some data limitations, we do not work with the universe of all labor market entrants but only with a specifically selected sample. First, we restrict our attention to male entrants only. On the one hand, female labor supply behavior over the life cycle is much more difficult to model than male labor supply. On the other hand, we believe that the fact that most men work full time allows us to largely circumvent the problem that the ASSD does not contain information on working hours. Second, we select those workers who start their first regular employment spell sometime between 1978 and 2000, allowing us to observe at least five additional years of earnings for each worker because the data run until the end of 2005 (see also the Appendix). As a final restriction, we focus on workers aged between 16 and 21 at the time they first enter the labor force (i.e., start their first regular employment spell). ${ }^{11}$ Essentially, this restriction excludes individuals with higher education (most importantly, individuals with a university degree), but it should include all or most individuals with an apprenticeship training or an education of similar length and scope, such as full-time vocational school. ${ }^{12}$ Our final sample thus consists of male low- and medium-skilled labor market entrants who started their first regular employment between 1978 and 2000. We can observe these workers' full labor market career from the year they first enter into the labor force until the year 2005.

\subsection{Sample description}

Because we can follow all individuals from the year of their first regular employment until the end of the data in the year 2005, the resulting data set would have been too large from a practical point of view. In the following, we therefore work with a $30 \%$ random sample of all labor market entrants aged between 16 and 21 when first entering into the labor force. This sample contains 217,587 unique individuals and about 3.35 million individual wage observations (i.e., observations at the level of individual $\times$ year).

Table 1 shows descriptive statistics for our final analysis sample. The first panel shows individual-level characteristics. The average labor market entrant in our

\footnotetext{
${ }^{11}$ Because the ASSD does not contain a comprehensive measure for schooling, we use age at entry into the labor force as proxy for education in the regressions below. To mitigate potential collinearity with year of birth and year of entry, we use a slightly different variable as proxy in the regressions. Specifically, we use the smaller of age at start of first regular employment and age at start of first registered unemployment spell.

${ }^{12}$ Several arguments motivate the restriction on schooling. First, the timing of first labor market entry, and thus the duration of schooling, may be endogenous. However, less-skilled workers are presumably less likely to manipulate the duration of schooling. Furthermore, unobserved heterogeneity resulting from, say, unobserved differences in inherent ability, is arguably a more urgent problem for workers with higher skills. Moreover, we believe that our proxy for schooling works best for workers with low education levels. Finally, only including less-skilled workers in the sample is an effective way of dealing with right-censored wages (see also the Appendix).
} 
Table 1 Summary statistics, male labor market entrants 1978-2000

\begin{tabular}{|c|c|c|}
\hline & Mean & Standard deviation \\
\hline \multicolumn{3}{|l|}{ Individual-level characteristics } \\
\hline Age at start of first regular job & 19.195 & $(1.007)$ \\
\hline Age at first entry into the labor force & 18.669 & $(1.431)$ \\
\hline Duration of first regular job (years) & 2.847 & $(4.335)$ \\
\hline Any unemployment before first job & 0.306 & $(0.461)$ \\
\hline Unemployment days before first job & 42.649 & $(101.181)$ \\
\hline Blue collar & 0.546 & $(0.498)$ \\
\hline White collar & 0.176 & $(0.380)$ \\
\hline \multicolumn{3}{|l|}{ Aggregate-level variables } \\
\hline State-level unemployment rate & 6.595 & $(2.897)$ \\
\hline NUTS-3 level unemployment rate & 6.645 & $(3.144)$ \\
\hline State-level youth unemployment rate & 4.941 & $(1.790)$ \\
\hline Number of entrants aged 16-21 & $3,767.283$ & $(1,451.150)$ \\
\hline \multicolumn{3}{|l|}{ State of first entry into the labor market } \\
\hline Vienna & 0.179 & $(0.383)$ \\
\hline Lower Austria & 0.173 & $(0.378)$ \\
\hline Burgenland & 0.025 & $(0.156)$ \\
\hline Upper Austria & 0.194 & $(0.395)$ \\
\hline Styria & 0.147 & $(0.354)$ \\
\hline Carinthia & 0.067 & $(0.251)$ \\
\hline Salzburg & 0.071 & $(0.256)$ \\
\hline Tyrol & 0.092 & $(0.289)$ \\
\hline Vorarlberg & 0.053 & $(0.223)$ \\
\hline \multicolumn{3}{|l|}{ Year of first entry into the labor market } \\
\hline 1978 & 0.033 & $(0.178)$ \\
\hline 1979 & 0.039 & $(0.194)$ \\
\hline 1980 & 0.046 & $(0.208)$ \\
\hline 1981 & 0.045 & $(0.207)$ \\
\hline 1982 & 0.042 & $(0.202)$ \\
\hline 1983 & 0.044 & $(0.206)$ \\
\hline 1984 & 0.048 & $(0.213)$ \\
\hline 1985 & 0.047 & $(0.212)$ \\
\hline 1986 & 0.046 & $(0.210)$ \\
\hline 1987 & 0.046 & $(0.210)$ \\
\hline 1988 & 0.048 & $(0.214)$ \\
\hline 1989 & 0.050 & $(0.217)$ \\
\hline 1990 & 0.049 & $(0.216)$ \\
\hline 1991 & 0.046 & $(0.209)$ \\
\hline 1992 & 0.042 & $(0.201)$ \\
\hline 1993 & 0.038 & $(0.190)$ \\
\hline
\end{tabular}


Table 1 (continued)

\begin{tabular}{lcc}
\hline & Mean & Standard deviation \\
\hline 1994 & 0.041 & $(0.198)$ \\
1995 & 0.040 & $(0.196)$ \\
1996 & 0.038 & $(0.192)$ \\
1997 & 0.040 & $(0.195)$ \\
1998 & 0.041 & $(0.197)$ \\
1999 & 0.043 & $(0.204)$ \\
2000 & 0.048 & $(0.214)$ \\
Number of unique individuals & 217,587 & \\
\hline
\end{tabular}

All aggregate-level variables are computed from the individual-level raw data of the ASSD (see footnote 10). See also notes of Table 10

sample is about 19 years old when starting his first regular employment spell, and he holds his first job for almost 3 years. The average age at the start of the first job dovetails with the fact that mandatory schooling ends in the year when individuals attain the age of 16 and that apprenticeships usually last for 2 to 4 years. The high fraction of blue-collar occupations is consistent with our intention of only (or mainly) including individuals who received some kind of vocational training. Interestingly, a substantial fraction of the sample (about a third) experiences some unemployment before starting the first regular employment spell (these individuals are registered for unemployment benefits on average for somewhat more than 1 month). Consistent with this, we find that age at first entry (our proxy for schooling) is about half a year lower than age at the start of the first regular job, reflecting the fact that the transition from education to work often involves short periods of nonemployment.

The second panel shows various unemployment rates as well as the number of labor market entrants. The different unemployment rates use different aggregation levels (cf. footnote 10) and refer to different age groups, but all of them are limited to the male population only. The unemployment rate in the year of labor market entry averages about $6.6 \%$, irrespective of the chosen aggregation level (states or NUTS3 units). Youth unemployment rates at the time of entry are somewhat lower than overall unemployment rates and equal about $5 \%$ on average. Finally, about 3,750 male individuals aged between 16 and 21 enter the labor market in any given state and year in the period 1978-2000.

The remaining part of the table shows the distribution of our sample of labor market entrants across the nine different states and across years. The distribution across states mainly reflects differences in population size. It may, however, also reflect other differences between states (e.g., differences in the age distribution of women). The distribution of entrants across years on the other hand looks fairly uniform, implying that the aggregate number of entrants aged between 16 and 21 has not changed much over time. 


\section{The persistence of initial labor market shocks}

\subsection{Graphical evidence on the evolution of wages and initial conditions}

We start with a simple graphical depiction of our two key measures (i.e., cohorts' wage profiles and the initial local unemployment rate). First, Fig. 1 shows wage profiles by entry cohort for all labor market cohorts who first entered the labor force between 1978 and 2000. The black dots therefore represent average starting wages for each entry cohort, and the dashed gray line thus shows how starting wages evolve over time. Clearly, real starting wages have increased significantly over the period of analysis, from about $38 €$ in 1978 to about $50 €$ in 2000 . Also note that there is some cyclical movement in starting wages over time which we expect to be related to economic conditions prevailing in that year.

The solid colored lines, on the other hand, represent long-run wage profiles of cohorts entering the labor market in different years. Cohorts' wages clearly follow an approximate concave path over time, implying that wage growth is highest in earlier working years and then strongly flattens later on. The figure shows, for example, that the 1978 entry cohort starts with a real wage of about $38 €$ per workday and experiences a raise in real wage up to about $97 €$ by the year 2005 . On average, this cohort's compensation therefore more than doubles in real terms within the first 27 years of labor market experience. Focusing again on the 1978 entry cohort, we see that this cohort's average wage grows by approximately $146 \%(=[\exp (0.9)-1] \cdot 100 \%)$

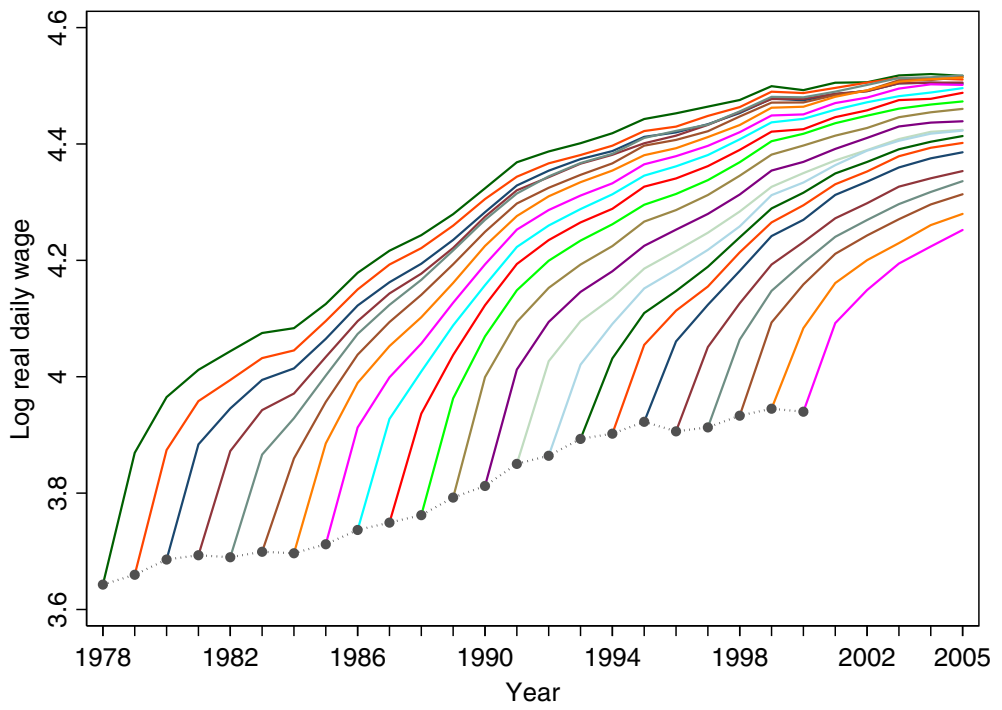

Fig. 1 Long-run wage profiles, by labor market entry cohort. The figure shows average log real daily wages by calendar year for each labor market entry cohort from 1978 to 2000. The dots thus show average $\log$ starting wages for each labor market entry cohort, and the dotted line highlights the evolution of starting wages. The filled lines show how entry cohorts' wages evolve with increasing labor market experience 
in the first 27 years of experience. Evidently, most of this wage increase happens at the early stage of the labor market career (i.e., the wage increase in the first 10 years equals about $86 \%(=[\exp (0.62)-1] \cdot 100 \%)){ }^{13}$

Panel (a) of Fig. 2 shows the evolution of state-level unemployment rates which we use as our indicator for external labor market conditions at the time individuals first enter the labor force. This figure shows that the period from 1978 to 2000 covers several periods of both boom and downturn, and that the identifying variation in initial labor market conditions therefore does not only stem from a few neighboring labor market cohorts. The figure also illustrates that states not only differ in the level of unemployment but also with respect to cyclical variations around a longer-run trend: although all states see an increase over the whole observation period in general, there are marked cyclical differences across states. ${ }^{14}$ The lower panel of Fig. 2 shows that our observation period spans several ups and downs in the business cycle, and that there is considerable differentiation in the strength of these variations across states. We thus have both sufficient cross-sectional and longitudinal variation in our key regressor that we can use to pin down the effect of local business cycle fluctuations on wages.

\subsection{Econometric framework}

Because we primarily aim to estimate the long-run impact of economic shocks at the time individuals started their first jobs, we must take care to allow the association between initial conditions and wage to become weaker or stronger as labor market experience increases while also using a generally flexible functional form of wage profiles. Taking these issues into account, our basic and most parsimonious econometric model is the following:

$$
\ln \left(y_{i t}\right)=\operatorname{ur}_{j[i]}^{0} \alpha_{1}+\kappa\left(\exp _{i t}\right) \alpha_{2}+\left[\operatorname{ur}_{j[i]}^{0} \cdot \kappa\left(\exp _{i t}\right)\right] \alpha_{3}+\psi_{i}^{j\left(t_{0}\right)}+\phi_{i}^{t_{0}}+\theta_{t}+\epsilon_{i t},
$$

where $y_{i t}$ denotes the real daily wage of individual $i$ in calendar year $t, \exp _{i t}$ the potential labor market experience of $i$ in year $t$, and $u_{j}^{0}{ }_{j i i]}$ the unemployment rate as prevailing in state $j$ at the time individual $i$ first entered the labor market. Function $\kappa(\cdot)$ denotes that we allow for a flexible functional form with respect to labor market

\footnotetext{
${ }^{13}$ Wage profiles of different entry cohorts have somewhat distinct overall shapes. More specifically, the figure shows that returns to experience generally decrease over time, meaning that younger entry cohorts have considerably lower returns to labor market experience than older cohorts. For example, the 1995 cohort only realizes an average wage increase of about $58 \%(=[\exp (.46)-1] \cdot 100 \%)$ in the first 10 years, thus less smaller than that of the corresponding increase of the 1978 entry cohort.

${ }^{14}$ For example, and as highlighted in the figure, Burgenland (located in southeastern Austria) experienced a huge increase in the unemployment rate from about $3 \%$ in the late 1970 s to about $8 \%$ in the first half of the 1980s, and then to about $9 \%$ in the second half of the 1980s. Vorarlberg (situated in western Austria), in contrast, experienced only a modest increase from about $1 \%$ on the 1970 s to about $3 \%$ in the 1980s. In 1992, however, Vorarlberg underwent a sharp decline in the local labor market conditions, when unemployment jumped from about $3 \%$ to about $7-8 \%$.
} 


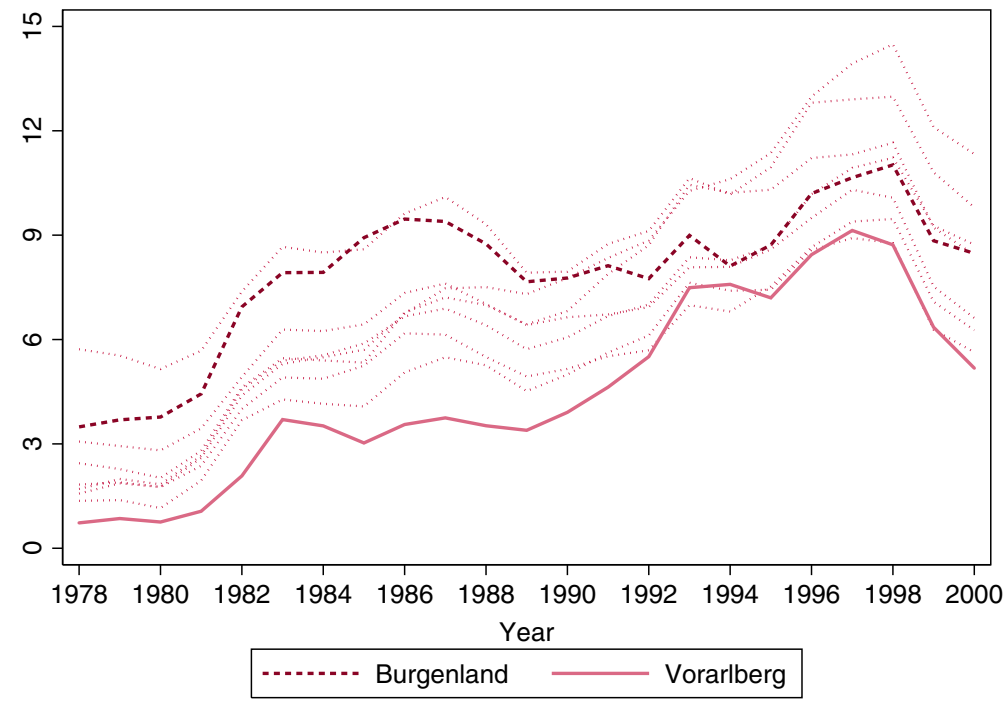

(a) Unemployment rate (in \%)

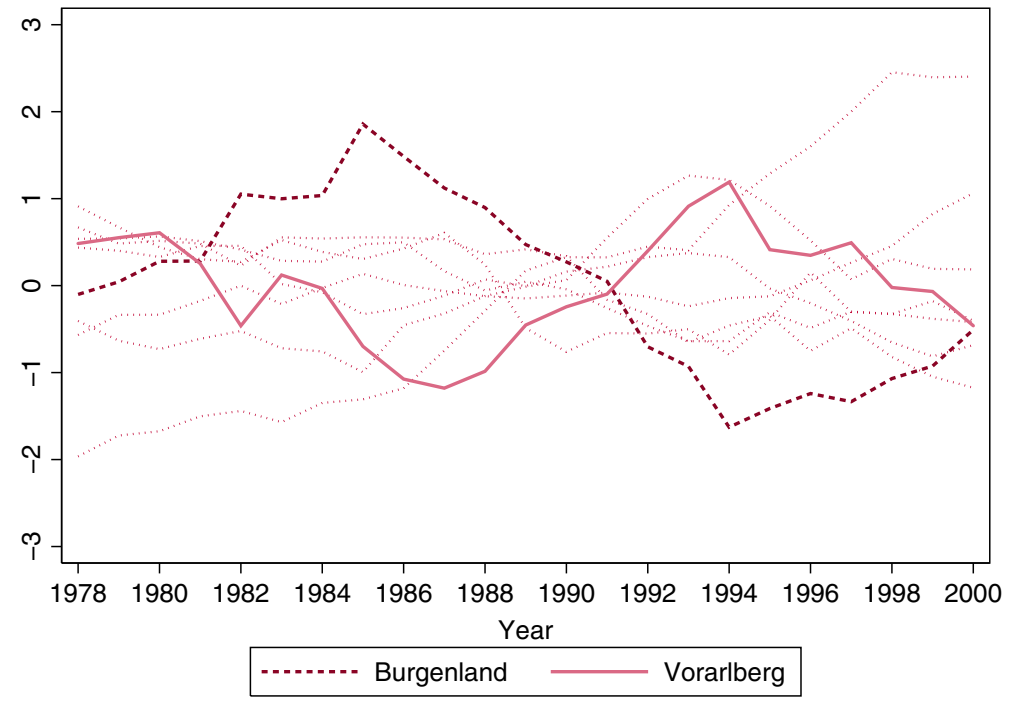

(b) Residual unemployment rate (in \%)

Fig. 2 a Fluctuations in state-level unemployment rates, 1978-2000. The figure shows male unemployment rates for workers aged between 16 and 65, aggregated at the level of the state ("Bundesland") and computed from the individual-level raw data of the ASSD. Two of the nine states are graphically highlighted. "Vorarlberg" is situated in the western part of Austria (bordering Germany and Switzerland). "Burgenland" is located at the eastern border of Austria (bordering Hungary in the east and Slovenia in the south). b Residuals from a regression of the initial unemployment rate on a full set of year and state of entry dummies 
experience. ${ }^{15}$ Note that we allow the effect of the initial unemployment rate on current wages to vary as potential labor market experience increases by including the interaction terms between the experience polynomials and the initial unemployment rate. We also include a full set of dummies for state at entry and year of entry, denoted by $\psi_{i}^{j\left(t_{0}\right)}$ and $\phi_{i}^{t_{0}}$, respectively, throughout the analysis. Finally, we also control for the aggregate business cycle $\theta_{t}$ which we parameterize using the aggregate yearly unemployment rate, the log aggregate number of workers, as well as log aggregate annual earnings.

As we will discuss in more detail below, our baseline (i.e., our preferred) specification will include some additional regressors:

$$
\begin{aligned}
\ln \left(y_{i t}\right)= & \operatorname{ur}_{j[i]}^{0} \alpha_{1}+\kappa\left(\exp _{i t}\right) \alpha_{2}+\left[\operatorname{ur}_{j[i]}^{0} \cdot \kappa\left(\exp _{i t}\right)\right] \alpha_{3}+\psi_{i}^{j\left(t_{0}\right)}+\phi_{i}^{t_{0}}+\theta_{t} \\
& +x_{i}^{0} \beta_{1}+\left[\phi_{i}^{t_{0}} \cdot \kappa\left(\exp _{i t}\right)\right] \beta_{2}+\ln \left(n_{j[i]}^{0}\right) \beta_{3}+\epsilon_{i t},
\end{aligned}
$$

where the second row contains these additional variables. First, $x_{i}^{0}$ denotes a small set of individual-level controls, i.e., our proxy for schooling and two indicator variables for workers' initial occupation (blue or white collar). These variables are predetermined in the sense that they relate to an individual's first regular employment spell or to the time before having started to work (i.e., there is no time index for these variables). We also include the full set of interaction terms between the year of entry and the polynomial in potential experience as well as the log number of labor market entrants aged 16-21 and aged 22-30 at the state level. The latter two variables are included to control for changes in the relative number of entrants aged 16-21 (relative to all entrants aged in the age bracket 16-30); the former set of controls allows for cohort-specific differences in the wage profile that are unrelated to differences in local initial unemployment rates but due to, say, changes in the production of education across cohorts.

In either case, parameters $\alpha_{1}$ to $\alpha_{3}$ describe individuals' wage-experience profiles as a function of the initial unemployment rate and are the parameters of main interest. Specifically, $\alpha_{1}$ is the elasticity of wages with respect to the initial unemployment rate in the year of first entry (i.e., in the year where labor market experience is equal to 0 ), while $\alpha_{3}$ tells us how the effect of initial conditions changes as labor market experience increases.

One important complication of both specifications relates to the fact that the local initial unemployment rate does not vary over time for any given individual. For this reason, we cannot use standard panel data estimators such as the fixed-effects or first-differences estimator because these methods not only eliminate all unobserved time-invariant heterogeneity but also all variation in the key regressor. We therefore rely on estimation methods that use the untransformed data. We also have to consider that our key regressor is observed at a higher level of aggregation than the dependent

\footnotetext{
${ }^{15}$ Specifically, we include the first three polynomial terms of potential labor market experience. We chose the number of polynomial terms on the basis of a nonparametric, and therefore fully flexible, wageexperience model. The first three polynomial terms appear sufficient for reproducing the wage-experience profile that a corresponding nonparametric specification predicts.
} 
variable, a situation that may lead to grossly misleading statistical inference (Moulton 1986). All standard errors we report are therefore clustered by cells defined by year at first entry $\times$ state of first entry (there are 9 states and 23 entry years, resulting in 207 distinct cells). ${ }^{16}$

\subsection{Main results: initial labor market conditions and wages}

Table 2 shows our main results, building up from our most parsimonious specification represented by Eq. 1 to our preferred specification as given by Eq. 2. The top panel of the table shows, for each specification, point estimates of the parameters describing the effect of initial conditions on wages (i.e., $\alpha_{1}$, the coefficient on the local initial unemployment rate, and $\alpha_{3}$, which represents the three interaction terms between the local initial unemployment rate and years of labor market experience, its square, and its cube, respectively), and the panel in the middle of the table shows estimated semielasticities of wages with respect to the initial local unemployment rate at specific values of potential labor market experience (i.e., potential labor market experience of $0,5,10,15$, and 20 years, respectively). For example, $\varepsilon_{\text {ur }}^{y}(5)$ denotes the estimated semi-elasticity of the real daily wage with respect to the initial unemployment rate at 5 years of potential labor market experience. It thus corresponds to the estimated relative change in wages resulting from a one percentage point increase in the initial unemployment rate.

The first column shows point estimates for our most parsimonious specification as spelled out in Eq. 1. As expected, there is a negative effect of the initial local unemployment on wages in the year of entry. Specifically, the semi-elasticity of wages with respect to the initial unemployment rate equals -0.009 in the year of entry. A one percentage point increase in the local initial unemployment rate is thus predicted to lower starting wages by $0.9 \%$. The corresponding standard error equals 0.002 , and thus the immediate wage effect is statistically highly significant. Moreover, the middle panel of the table shows that there is substantial persistence of this negative wage effect, and a negative and significant effect of initial labor market conditions remains as much as 20 years after the first entry into the labor market. In fact, the point estimate of the semi-elasticity at 20 years of experience is even larger than the immediate wage penalty.

We add our small set of individual-level controls (i.e., our proxy for schooling and two dummy variables indicating a worker's initial occupation) in the second specification. This has some impact on the estimated wage effects, especially in the year of entry into the labor market (the immediate semi-elasticity of wages decreases from 0.009 to 0.007 ), but otherwise, the coefficients are remarkably similar, and a negative and strongly persistent wage effect of bad entry conditions remains, as the middle panel of Table 2 reflects.

We replace our set of longitudinal controls with a set of biannual year dummies in the third column. This yields estimates that are very similar to those from the

\footnotetext{
${ }^{16}$ We also computed standard errors that simultaneously account for clustering at both levels for our main estimates. This yields standard errors that are virtually indistinguishable from those actually reported.
} 
Table 2 The long-run wage effects of initial labor market conditions

\begin{tabular}{|c|c|c|c|c|c|c|}
\hline \multirow{3}{*}{$\begin{array}{l}\text { Dependent variable } \\
\text { Mean } \\
\text { Standard deviation }\end{array}$} & \multicolumn{6}{|c|}{$\ln$ (real daily wage) } \\
\hline & 4.257 & 4.257 & 4.257 & 4.257 & 4.257 & 4.257 \\
\hline & 0.380 & 0.380 & 0.380 & 0.380 & 0.380 & 0.380 \\
\hline $\mathrm{ur}^{0}$ & $\begin{array}{c}-0.009^{\star \star \star} \\
(0.002)\end{array}$ & $\begin{array}{c}-0.007^{\star \star \star} \\
(0.002)\end{array}$ & $\begin{array}{c}-0.009^{\star \star \star} \\
(0.002)\end{array}$ & $\begin{array}{c}-0.009^{\star \star \star} \\
(0.002)\end{array}$ & $\begin{array}{c}-0.010^{\star \star \star} \\
(0.002)\end{array}$ & $\begin{array}{c}-0.009^{\star \star \star} \\
(0.002)\end{array}$ \\
\hline $\exp \cdot \operatorname{ur}^{0}$ & $\begin{array}{c}0.000 \\
(0.000)\end{array}$ & $\begin{array}{c}0.000 \\
(0.000)\end{array}$ & $\begin{array}{l}0.001^{\star \star} \\
(0.000)\end{array}$ & $\begin{array}{l}0.001^{\star \star} \\
(0.000)\end{array}$ & $\begin{array}{c}0.000 \\
(0.000)\end{array}$ & $\begin{array}{c}0.000 \\
(0.000)\end{array}$ \\
\hline $\exp ^{2} \cdot \operatorname{ur}^{0}$ & $\begin{array}{c}-0.000^{\star \star \star} \\
(0.000)\end{array}$ & $\begin{array}{c}-0.000^{\star \star \star} \\
(0.000)\end{array}$ & $\begin{array}{c}-0.000^{\star \star \star} \\
(0.000)\end{array}$ & $\begin{array}{c}-0.000^{\star \star \star} \\
(0.000)\end{array}$ & $\begin{array}{r}-0.000^{\star} \\
(0.000)\end{array}$ & $\begin{array}{c}-0.000^{\star} \\
(0.000)\end{array}$ \\
\hline $\exp ^{3} \cdot \mathrm{ur}^{0}$ & $\begin{array}{l}0.000^{\star \star \star} \\
(0.000)\end{array}$ & $\begin{array}{l}0.000^{\star \star \star} \\
(0.000)\end{array}$ & $\begin{array}{l}0.000^{\star \star \star} \\
(0.000)\end{array}$ & $\begin{array}{l}0.000^{\star \star \star} \\
(0.000)\end{array}$ & $\begin{array}{c}0.000^{\star} \\
(0.000)\end{array}$ & $\begin{array}{c}0.000^{\star} \\
(0.000)\end{array}$ \\
\hline$\varepsilon_{\mathrm{ur}}^{y}(0)$ & $\begin{array}{c}-0.009^{\star \star \star} \\
(0.002)\end{array}$ & $\begin{array}{c}-0.007^{\star \star \star} \\
(0.002)\end{array}$ & $\begin{array}{c}-0.009^{\star \star \star} \\
(0.002)\end{array}$ & $\begin{array}{c}-0.009^{\star \star \star} \\
(0.002)\end{array}$ & $\begin{array}{c}-0.010^{\star \star \star} \\
(0.002)\end{array}$ & $\begin{array}{c}-0.009^{\star \star \star} \\
(0.002)\end{array}$ \\
\hline$\varepsilon_{\mathrm{ur}}^{y}(5)$ & $\begin{array}{c}-0.011^{\star \star \star} \\
(0.002)\end{array}$ & $\begin{array}{c}-0.010^{\star \star \star} \\
(0.002)\end{array}$ & $\begin{array}{c}-0.010^{\star \star \star} \\
(0.002)\end{array}$ & $\begin{array}{c}-0.010^{\star \star \star} \\
(0.002)\end{array}$ & $\begin{array}{c}-0.010^{\star \star \star} \\
(0.001)\end{array}$ & $\begin{array}{c}-0.009^{\star \star \star} \\
(0.001)\end{array}$ \\
\hline$\varepsilon_{\mathrm{ur}}^{y}(10)$ & $\begin{array}{c}-0.017^{\star \star \star} \\
(0.002)\end{array}$ & $\begin{array}{c}-0.016^{\star \star \star} \\
(0.002)\end{array}$ & $\begin{array}{c}-0.015^{\star \star \star} \\
(0.002)\end{array}$ & $\begin{array}{c}-0.015^{\star \star \star} \\
(0.001)\end{array}$ & $\begin{array}{c}-0.012^{\star \star \star} \\
(0.001)\end{array}$ & $\begin{array}{c}-0.012^{\star \star \star} \\
(0.001)\end{array}$ \\
\hline$\varepsilon_{\mathrm{ur}}^{y}(15)$ & $\begin{array}{c}-0.021^{\star \star \star} \\
(0.002)\end{array}$ & $\begin{array}{c}-0.020^{\star \star \star} \\
(0.002)\end{array}$ & $\begin{array}{c}-0.019^{\star \star \star} \\
(0.002)\end{array}$ & $\begin{array}{c}-0.019^{\star \star \star} \\
(0.002)\end{array}$ & $\begin{array}{c}-0.015^{\star \star \star} \\
(0.002)\end{array}$ & $\begin{array}{c}-0.014^{\star \star \star} \\
(0.001)\end{array}$ \\
\hline$\varepsilon_{\mathrm{ur}}^{y}(20)$ & $\begin{array}{c}-0.015^{\star \star \star} \\
(0.003)\end{array}$ & $\begin{array}{c}-0.015^{\star \star \star} \\
(0.002)\end{array}$ & $\begin{array}{c}-0.014^{\star \star \star} \\
(0.003)\end{array}$ & $\begin{array}{c}-0.014^{\star \star \star} \\
(0.003)\end{array}$ & $\begin{array}{c}-0.018^{\star \star \star} \\
(0.002)\end{array}$ & $\begin{array}{c}-0.017^{\star \star \star} \\
(0.002)\end{array}$ \\
\hline Potential experience & Yes & Yes & Yes & Yes & Yes & Yes \\
\hline Longitudinal controls & Yes & Yes & No & Yes & Yes & Yes \\
\hline Year of entry & Yes & Yes & Yes & Yes & Yes & Yes \\
\hline Region of entry & Yes & Yes & Yes & Yes & Yes & Yes \\
\hline Individual controls & No & Yes & Yes & Yes & Yes & Yes \\
\hline Time dummies (biannual) & No & No & Yes & Yes & No & No \\
\hline Year of entry $\times \kappa(\exp )$ & No & No & No & No & Yes & Yes \\
\hline Number of entrants & No & No & No & No & No & Yes \\
\hline Number of observations & $3,349,075$ & $3,349,075$ & $3,349,075$ & $3,349,075$ & $3,349,075$ & $3,349,075$ \\
\hline Adjusted $R$-squared & 0.286 & 0.325 & 0.326 & 0.326 & 0.327 & 0.327 \\
\hline Lifetime loss & 0.016 & 0.015 & 0.015 & 0.014 & 0.013 & 0.013 \\
\hline
\end{tabular}

Robust standard errors are given in parentheses and are clustered by state at entry $\times$ year of entry. exp and $u^{0}$ denote potential labor market experience (in years) and the initial unemployment rate (in percentages), respectively. $\varepsilon_{\mathrm{ur}}^{y}(k)$ denotes the estimated semi-elasticity of wages with respect to the initial unemployment rate, evaluated at $k$ years of potential labor market experience

${ }^{\star} p<0.1 ;{ }^{\star \star} p<0.05 ;{ }^{\star \star \star} p<0.01$ (statistical significance) 
specification with parametric business cycle controls. The fourth column includes both the set of biannual year dummies and our set of parametric longitudinal controls. Again, the estimates hardly change, although the estimated semi-elasticities at higher values of labor market experience are somewhat smaller than in the specification with only a parameterized trend.

We next add the full set of interaction terms between the year of entry and the experience terms. This allows for changes in the wage profile across entry cohorts that are unrelated to initial conditions in a fully flexible way. The estimates again remain more or less stable.

We finally add the log number of labor market entrants aged 16-21 and 22-30 in the sixth column because there was a substantive drop in the relative number of labor market entrants aged 16-21 relative to all entrants aged below 30. The specification underlying the estimates shown in column 6 thus corresponds to the specification of Eq. 2. Our baseline specification still yields an immediate negative and statistically significant wage effect of about -0.009 . Moreover, we find the wage penalty resulting from entering the labor market in times of high local unemployment to be highly persistent. In fact, the wage penalty is even slightly increasing with labor market experience, similar to what is found by Stevens (2007).

\subsection{Robustness}

Table 3 presents some different robustness checks. For the ease of comparison, the first column simply reproduces our baseline estimates from column 6 of Table 2 .

A first robustness check relates to the fact that a nonnegligible number of wage observations is censored. ${ }^{17}$ Column 2 thus shows quantile (i.e., median) regression estimates of our baseline specification. The short-run estimates are identical, but the estimated wage losses turn out to be moderately larger at higher values of labor market experience. More specifically, $\varepsilon_{\text {ur }}^{0}(5)$ is already slightly larger when estimated using a quantile regression, but the quantile regression estimate of $\varepsilon_{\mathrm{ur}}^{0}(20)$ is as much as $35 \%$ larger than the corresponding ordinary least squares (OLS) estimate. If anything, censored wages will thus lead us to underestimate the wage effects resulting from labor market entry in times of high local unemployment.

We add the interaction terms between our longitudinal controls and the experience terms in the third column to allow for the possibility that variations in the business cycle affect workers differentially at different stages of their labor market career. This, however, has no discernible effect on the estimated coefficients of our key parameters. Most of the estimated semi-elasticities are virtually identical to our baseline estimates.

We use different unemployment rates in columns 4 and 5 as another robustness check. We use unemployment rates at the NUTS-3 rather than at the state level in the fourth column (cf. footnote 10). Using the unemployment rate at the NUTS-3 level results in a smaller initial and a somewhat less persistent wage effect. This

\footnotetext{
${ }^{17}$ Appendix Table 10 shows that only few wage observations are censored in the year of entry. However, top-censored wages become much more frequent as workers accumulate labor market experience.
} 
Table 3 Sensitivity analysis

\begin{tabular}{|c|c|c|c|c|c|c|}
\hline \multirow{3}{*}{$\begin{array}{l}\text { Dependent variable } \\
\text { Mean } \\
\text { Standard deviation }\end{array}$} & \multicolumn{5}{|c|}{$\ln ($ real daily wage $)$} & \multirow{2}{*}{$\begin{array}{l}\ln \text { (earnings) } \\
9.991\end{array}$} \\
\hline & 4.257 & 4.257 & 4.257 & 4.257 & 4.257 & \\
\hline & 0.380 & 0.380 & 0.380 & 0.380 & 0.380 & 0.656 \\
\hline$u^{0}$ & $\begin{array}{c}-0.009^{\star \star \star} \\
(0.002)\end{array}$ & $\begin{array}{c}-0.009^{\star \star \star} \\
(0.000)\end{array}$ & $\begin{array}{c}-0.009^{\star \star \star} \\
(0.002)\end{array}$ & $\begin{array}{c}-0.005^{\star \star \star} \\
(0.001)\end{array}$ & $\begin{array}{c}-0.006^{\star \star \star} \\
(0.002)\end{array}$ & $\begin{array}{c}-0.007^{\star \star \star} \\
(0.003)\end{array}$ \\
\hline $\exp \cdot$ ur $^{0}$ & $\begin{array}{c}0.000 \\
(0.000)\end{array}$ & $\begin{array}{r}-0.000 \\
(0.000)\end{array}$ & $\begin{array}{c}0.000 \\
(0.000)\end{array}$ & $\begin{array}{r}-0.000 \\
(0.000)\end{array}$ & $\begin{array}{c}-0.001^{\star \star} \\
(0.000)\end{array}$ & $\begin{array}{r}-0.001^{\star} \\
(0.001)\end{array}$ \\
\hline $\exp ^{2} \cdot u^{0}$ & $\begin{array}{r}-0.000^{\star} \\
(0.000)\end{array}$ & $\begin{array}{c}-0.000^{\star \star} \\
(0.000)\end{array}$ & $\begin{array}{c}-0.000^{\star} \\
(0.000)\end{array}$ & $\begin{array}{c}-0.000^{\star \star} \\
(0.000)\end{array}$ & $\begin{array}{c}0.000 \\
(0.000)\end{array}$ & $\begin{array}{c}0.000 \\
(0.000)\end{array}$ \\
\hline $\exp ^{3} \cdot \operatorname{ur}^{0}$ & $\begin{array}{c}0.000^{\star} \\
(0.000)\end{array}$ & $\begin{array}{c}0.000 \\
(0.000)\end{array}$ & $\begin{array}{l}0.000^{\star \star} \\
(0.000)\end{array}$ & $\begin{array}{l}0.000^{\star \star \star} \\
(0.000)\end{array}$ & $\begin{array}{c}0.000 \\
(0.000)\end{array}$ & $\begin{array}{c}0.000 \\
(0.000)\end{array}$ \\
\hline$\varepsilon_{\mathrm{ur}}^{y}(0)$ & $\begin{array}{c}-0.009^{\star \star \star} \\
(0.002)\end{array}$ & $\begin{array}{c}-0.009^{\star \star \star} \\
(0.000)\end{array}$ & $\begin{array}{c}-0.009^{\star \star \star} \\
(0.002)\end{array}$ & $\begin{array}{c}-0.005^{\star \star \star} \\
(0.001)\end{array}$ & $\begin{array}{c}-0.006^{\star \star \star} \\
(0.002)\end{array}$ & $\begin{array}{c}-0.007^{\star \star \star} \\
(0.003)\end{array}$ \\
\hline$\varepsilon_{\mathrm{ur}}^{y}(5)$ & $\begin{array}{c}-0.009^{\star \star \star} \\
(0.001)\end{array}$ & $\begin{array}{c}-0.011^{\star \star \star} \\
(0.000)\end{array}$ & $\begin{array}{c}-0.009^{\star \star \star} \\
(0.001)\end{array}$ & $\begin{array}{c}-0.007^{\star \star \star} \\
(0.001)\end{array}$ & $\begin{array}{c}-0.011^{\star \star \star} \\
(0.002)\end{array}$ & $\begin{array}{c}-0.012^{\star \star \star} \\
(0.002)\end{array}$ \\
\hline$\varepsilon_{\mathrm{ur}}^{y}(10)$ & $\begin{array}{c}-0.012^{\star \star \star} \\
(0.001)\end{array}$ & $\begin{array}{c}-0.015^{\star \star \star} \\
(0.000)\end{array}$ & $\begin{array}{c}-0.012^{\star \star \star} \\
(0.001)\end{array}$ & $\begin{array}{c}-0.010^{\star \star \star} \\
(0.001)\end{array}$ & $\begin{array}{c}-0.014^{\star \star \star} \\
(0.002)\end{array}$ & $\begin{array}{c}-0.016^{\star \star \star} \\
(0.002)\end{array}$ \\
\hline$\varepsilon_{\mathrm{ur}}^{y}(15)$ & $\begin{array}{c}-0.014^{\star \star \star} \\
(0.001)\end{array}$ & $\begin{array}{c}-0.019^{\star \star \star} \\
(0.000)\end{array}$ & $\begin{array}{c}-0.015^{\star \star \star} \\
(0.001)\end{array}$ & $\begin{array}{c}-0.013^{\star \star \star} \\
(0.001)\end{array}$ & $\begin{array}{c}-0.016^{\star \star \star} \\
(0.002)\end{array}$ & $\begin{array}{c}-0.019^{\star \star \star} \\
(0.002)\end{array}$ \\
\hline$\varepsilon_{\mathrm{ur}}^{y}(20)$ & $\begin{array}{c}-0.017^{\star \star \star} \\
(0.002)\end{array}$ & $\begin{array}{c}-0.023^{\star \star \star} \\
(0.000)\end{array}$ & $\begin{array}{c}-0.017^{\star \star \star} \\
(0.002)\end{array}$ & $\begin{array}{c}-0.015^{\star \star \star} \\
(0.001)\end{array}$ & $\begin{array}{c}-0.017^{\star \star \star} \\
(0.002)\end{array}$ & $\begin{array}{c}-0.021^{\star \star \star} \\
(0.003)\end{array}$ \\
\hline Estimation method & OLS & LAD & OLS & OLS & OLS & OLS \\
\hline Unemployment rate & State & State & State & NUTS-3 & Youth & State \\
\hline Baseline controls & Yes & Yes & Yes & Yes & Yes & Yes \\
\hline Longitudinal controls $\times \kappa(\exp )$ & No & No & Yes & No & No & No \\
\hline Number of observations & $3,349,075$ & $3,349,075$ & $3,349,075$ & $3,349,075$ & $3,349,075$ & $3,349,075$ \\
\hline Adjusted $R$-squared & 0.327 & & 0.328 & 0.330 & 0.327 & 0.223 \\
\hline Lifetime loss & 0.013 & 0.016 & 0.013 & 0.010 & 0.014 & 0.016 \\
\hline
\end{tabular}

Robust standard errors are given in parentheses and are clustered by state at entry $\times$ year of entry. The specification in column 1 is the same as in column 6 of Table 2. All specifications include the same set of controls as in column 6 of Table 2 ("baseline controls"). The dependent variable is the $\log$ real daily wage in columns 1-5 and log real annual earnings in column 6 . We use the state unemployment rate for men aged 16-65 ("state") in columns 1-3 and 6, the NUTS-3 level unemployment rate for men aged 16-65 ("NUTS-3") in column 4, and the state-level unemployment rate for men aged 16-25 ("youth") in column 5

${ }^{\star} p<0.1 ;{ }^{\star \star} p<0.05 ;{ }^{\star \star \star} p<0.01$ (statistical significance)

is most likely due to the fact that we also include entry-region fixed effects at a finer aggregation level which tends to pick up more of the variation in wages. 
18 The specification in the fifth column uses state-level youth unemployment rates instead of overall unemployment rates. The resulting wage effects are somewhat larger but still reasonably close to our main estimates based on overall unemployment rates.

Finally, the specification in the sixth column shows results when we use log annual earnings instead of log daily wages as the dependent variable. In this case, we get somewhat larger, but still very similar estimates to those in the baseline case. The comparison with the effect on wages also implies that workers entering during times of high local unemployment not only suffer from lower subsequent wages, but also from fewer employment days throughout their labor market career (see also our Electronic Supplementary Material (ESM) where we discuss the effect of initial conditions on job mobility and unemployment).

\subsection{Endogenous labor market entry}

\section{Instrumental variable estimates}

One important issue that we have not yet considered is the fact that the composition of the sample of labor market entrants may be endogenous with respect to variation in the local business cycle, which may lead to inconsistent estimates of the effect of initial conditions on wages. ${ }^{19}$ Various studies have tried to tackle this issue by instrumenting the unemployment rate at labor market entry with the unemployment rate at some earlier age or with the unemployment rate at the predicted date of graduation. ${ }^{20}$ We have thus tried a similar approach, instrumenting the local unemployment rate at entry with the local unemployment rate at age 16 , the age at which mandatory schooling ends in Austria.

However, we have some serious reservations, at least in our context, regarding the validity of this instrumental variable strategy. Most importantly, the instrument may have a direct effect on subsequent wages, in which case IV estimates will be biased (e.g., Angrist and Krueger 1994). To see why this may occur, note that the majority

\footnotetext{
${ }^{18}$ It may also reflect endogeneity of the local unemployment rate at lower aggregation levels, due to the fact that workers move from regions with high unemployment to those with lower levels of unemployment (Wozniak 2010).

${ }^{19}$ Bils (1985) and more recently Solon et al. (1994) and Blundell et al. (2003) have put forth this line of argument. In fact, the timing of labor force entry and thus the composition of labor market cohorts may be endogenous for several distinct reasons. First, some potential labor market entrants may refrain from entering the labor market altogether. Second, both the choice of education as well as the duration of schooling may be endogenous, as both job prospects are weak and opportunity costs of schooling are low in times of high unemployment. Third, some workers may simply delay their entry when faced with unfavorable entry conditions, either by registering for unemployment benefits or by staying out of the labor force until they find a job. Whatever the underlying reason, if those workers who do not immediately get a job are a selected group of all workers who intend to enter employment in a given year, then the composition of the actual entrants changes along with corresponding changes in the unemployment rate and thus potentially biases the estimated effect of the initial unemployment rate on wages.

${ }^{20} \mathrm{Kahn}$ (2010), Kondo (2008) and Oreopoulos et al. (2012) use a similar instrumental variable strategy. OLS and IV estimates are similar to those of Oreopoulos et al. (2012), but IV are substantially larger to those of both Kondo (2008) and Kahn (2010). Two European studies, by Kwon et al. (2010) and Stevens (2007), only show OLS estimates.
} 
of individuals, at least in our sample, start an apprenticeship training at the age of 16, as this is the age when mandatory schooling ends. In Austria, moreover, most of the practical training is directly provided by firms which are free to decide whether they want to offer apprenticeships. It is thus quite obvious that labor market conditions may have an impact on firms' decision to offer apprenticeships. ${ }^{21}$ Moreover, economic conditions may not only impact the number, but also the type (i.e., quality) of apprenticeship firms offer.

Table 4 shows OLS and instrumental variable estimates. As before, the first column replicates our baseline estimates from column 6 of Table 2. We first compare our baseline estimates to the corresponding 2SLS estimates that instrument the local unemployment rate at first entry with the local unemployment rate at age 16, shown in the fifth column. The 2SLS estimate of the semi-elasticity in the year of entry into the labor force is more than six times larger than the corresponding OLS estimate $(-0.059$ versus -0.009$)$, and the lifetime loss in the case of 2SLS is about four times larger than in the baseline case $(0.052$ versus 0.013$)$. While it appears reasonable that 2SLS estimates are larger than OLS estimates, signifying positive sample selection in economic downturns, the size of the difference between the estimates is almost suspiciously large. Thus, let us examine the reduced form estimates as well, shown in column 3. Note that the immediate and medium-run wage losses are considerably larger than those in column 1, while the estimates appear to converge at higher values of labor market experience. It seems hard to rationalize the difference between columns 1 and 3 without considering the possibility of a direct effect of ur ${ }^{16}$ on the dependent variable.

Finally, since both our proxy for the completed duration of schooling and/or training as well as individuals' initial occupation may be endogenous with respect to the unemployment rate age 16, we also show estimates that do not control for these characteristics. Our baseline estimates are hardly any different, but note that the estimates using the unemployment rate at age 16 increase considerably, resulting in 2SLS estimates that are as much as ten times larger than the corresponding OLS estimates (compare columns 6 and 2). These estimates are presumably too large to be plausible, but we think that they can be easily rationalized by acknowledging that the instrument has a direct impact on wages (through its impact on individuals' schooling/training) in which case 2SLS estimates are upwards biased.

\section{Direct evidence on endogenous labor market entry}

We complement the evidence from our IV estimates with some more direct evidence on compositional effects from labor market entry conditions. A first piece of evidence is provided in Table 5 that directly examines the association of entry conditions

\footnotetext{
${ }^{21}$ To the best of our knowledge, there is no relevant empirical evidence for Austria. However, Muehlemann et al. (2009) provide evidence consistent with this line of argument for Switzerland, which has an apprenticeship system very similar to that of Austria. Their results thus presumably carry over to Austria.
} 
Table 4 OLS versus 2SLS estimates

\begin{tabular}{|c|c|c|c|c|c|c|}
\hline \multirow{3}{*}{$\begin{array}{l}\text { Dependent variable } \\
\text { Mean } \\
\text { Standard deviation }\end{array}$} & \multicolumn{6}{|c|}{$\ln ($ real daily wage $)$} \\
\hline & 4.257 & 4.257 & 4.257 & 4.257 & 4.257 & 4.257 \\
\hline & 0.380 & 0.380 & 0.380 & 0.380 & 0.380 & 0.380 \\
\hline $\mathrm{ur}^{0}$ & $\begin{array}{c}-0.009^{\star \star \star} \\
(0.002)\end{array}$ & $\begin{array}{c}-0.011^{\star \star \star} \\
(0.002)\end{array}$ & & & $\begin{array}{c}-0.059^{\star \star \star} \\
(0.006)\end{array}$ & $\begin{array}{c}-0.135^{\star \star \star} \\
(0.017)\end{array}$ \\
\hline $\exp \cdot u r^{0}$ & $\begin{array}{c}0.000 \\
(0.000)\end{array}$ & $\begin{array}{c}0.000 \\
(0.000)\end{array}$ & & & $\begin{array}{l}0.005^{\star \star \star} \\
(0.001)\end{array}$ & $\begin{array}{l}0.005^{\star \star \star} \\
(0.001)\end{array}$ \\
\hline $\exp ^{2} \cdot u^{0}$ & $\begin{array}{r}-0.000^{\star} \\
(0.000)\end{array}$ & $\begin{array}{r}-0.000 \\
(0.000)\end{array}$ & & & $\begin{array}{c}-0.001^{\star \star \star} \\
(0.000)\end{array}$ & $\begin{array}{c}-0.001^{\star \star \star} \\
(0.000)\end{array}$ \\
\hline $\exp ^{3} \cdot \mathrm{ur}^{0}$ & $\begin{array}{c}0.000^{\star} \\
(0.000)\end{array}$ & $\begin{array}{c}0.000 \\
(0.000)\end{array}$ & & & $\begin{array}{l}0.000^{\star \star \star} \\
(0.000)\end{array}$ & $\begin{array}{l}0.000^{\star \star \star} \\
(0.000)\end{array}$ \\
\hline $\mathrm{ur}^{16}$ & & & $\begin{array}{c}-0.029^{\star \star \star} \\
(0.002)\end{array}$ & $\begin{array}{c}-0.052^{\star \star \star} \\
(0.003)\end{array}$ & & \\
\hline $\exp \cdot u^{16}$ & & & $\begin{array}{l}0.004^{\star \star \star} \\
(0.001)\end{array}$ & $\begin{array}{l}0.004^{\star \star \star} \\
(0.001)\end{array}$ & & \\
\hline $\exp ^{2} \cdot \operatorname{ur}^{16}$ & & & $\begin{array}{c}-0.000^{\star \star \star} \\
(0.000)\end{array}$ & $\begin{array}{c}-0.000^{\star \star \star} \\
(0.000)\end{array}$ & & \\
\hline $\exp ^{3} \cdot \operatorname{ur}^{16}$ & & & $\begin{array}{l}0.000^{\star \star \star} \\
(0.000)\end{array}$ & $\begin{array}{l}0.000^{\star \star \star} \\
(0.000)\end{array}$ & & \\
\hline$\varepsilon_{\mathrm{ur}}^{y}(0)$ & $\begin{array}{c}-0.009^{\star \star \star} \\
(0.002)\end{array}$ & $\begin{array}{c}-0.011^{\star \star \star} \\
(0.002)\end{array}$ & $\begin{array}{c}-0.029^{\star \star \star} \\
(0.002)\end{array}$ & $\begin{array}{c}-0.052^{\star \star \star} \\
(0.003)\end{array}$ & $\begin{array}{c}-0.059^{\star \star \star} \\
(0.006)\end{array}$ & $\begin{array}{c}-0.135^{\star \star \star} \\
(0.017)\end{array}$ \\
\hline$\varepsilon_{\mathrm{ur}}^{y}(5)$ & $\begin{array}{c}-0.009^{\star \star \star} \\
(0.001)\end{array}$ & $\begin{array}{c}-0.011^{\star \star \star} \\
(0.002)\end{array}$ & $\begin{array}{c}-0.015^{\star \star \star} \\
(0.002)\end{array}$ & $\begin{array}{c}-0.039^{\star \star \star} \\
(0.002)\end{array}$ & $\begin{array}{c}-0.044^{\star \star \star} \\
(0.005)\end{array}$ & $\begin{array}{c}-0.124^{\star \star \star} \\
(0.016)\end{array}$ \\
\hline$\varepsilon_{\mathrm{ur}}^{y}(10)$ & $\begin{array}{c}-0.012^{\star \star \star} \\
(0.001)\end{array}$ & $\begin{array}{c}-0.013^{\star \star \star} \\
(0.001)\end{array}$ & $\begin{array}{c}-0.015^{\star \star \star} \\
(0.002)\end{array}$ & $\begin{array}{c}-0.039^{\star \star \star} \\
(0.002)\end{array}$ & $\begin{array}{c}-0.045^{\star \star \star} \\
(0.005)\end{array}$ & $\begin{array}{c}-0.132^{\star \star \star} \\
(0.016)\end{array}$ \\
\hline$\varepsilon_{\mathrm{ur}}^{y}(15)$ & $\begin{array}{c}-0.014^{\star \star \star} \\
(0.001)\end{array}$ & $\begin{array}{c}-0.015^{\star \star \star} \\
(0.002)\end{array}$ & $\begin{array}{c}-0.019^{\star \star \star} \\
(0.002)\end{array}$ & $\begin{array}{c}-0.045^{\star \star \star} \\
(0.002)\end{array}$ & $\begin{array}{c}-0.053^{\star \star \star} \\
(0.005)\end{array}$ & $\begin{array}{c}-0.146^{\star \star \star} \\
(0.017)\end{array}$ \\
\hline$\varepsilon_{\mathrm{ur}}^{y}(20)$ & $\begin{array}{c}-0.017^{\star \star \star} \\
(0.002)\end{array}$ & $\begin{array}{c}-0.017^{\star \star \star} \\
(0.002)\end{array}$ & $\begin{array}{c}-0.021^{\star \star \star} \\
(0.002)\end{array}$ & $\begin{array}{c}-0.050^{\star \star \star} \\
(0.003)\end{array}$ & $\begin{array}{c}-0.055^{\star \star \star} \\
(0.006)\end{array}$ & $\begin{array}{c}-0.152^{\star \star \star} \\
(0.017)\end{array}$ \\
\hline Estimation method & OLS & OLS & OLS & OLS & 2SLS & 2SLS \\
\hline Baseline controls & Yes & Yes & Yes & Yes & Yes & Yes \\
\hline Individual controls & Yes & No & Yes & No & Yes & No \\
\hline Number of observations & $3,349,075$ & $3,349,075$ & $3,349,075$ & $3,349,075$ & $3,349,075$ & $3,349,075$ \\
\hline Adjusted $R$-squared & 0.327 & 0.287 & 0.328 & 0.296 & 0.323 & 0.249 \\
\hline Lifetime loss & 0.013 & 0.014 & 0.019 & 0.046 & 0.052 & 0.143 \\
\hline
\end{tabular}

Robust standard errors are given in parentheses and are clustered by state at entry $\times$ year of entry. The first column replicates the baseline estimates from column 6 of Table 2 . All specifications include controls for potential labor market experience, year of entry, state at entry, longitudinal controls, the interactions between year of entry and $\kappa(\exp )$, as well as controls for the number of labor market entrants ("baseline controls"). 2SLS estimates instrument the local unemployment rate at entry (ur ${ }^{0}$ ) with the local unemployment rate at age $16\left(\right.$ ur $\left.^{16}\right)$

${ }^{\star} p<0.1 ;{ }^{\star \star} p<0.05 ;{ }^{\star \star \star} p<0.01$ (statistical significance) 
Table 5 Number of labor market entrants

\begin{tabular}{llll}
\hline Dependent variable & \multicolumn{1}{l}{$\ln ($ no. of entrants) } & & \\
\cline { 2 - 4 } Mean & 7.782 & 7.058 & 8.229 \\
Standard deviation & 0.662 & 1.030 & 0.720 \\
\hline ur $^{0}$ & $-0.028^{\star \star \star}$ & 0.009 & -0.001 \\
& $(0.008)$ & $(0.012)$ & $(0.010)$ \\
Age of entrants & $16-21$ & $22-30$ & $16-30$ \\
State fixed effects & Yes & Yes & Yes \\
Time fixed effects & Yes & Yes & Yes \\
Number of observations & 207 & 207 & 207 \\
Adjusted $R$-squared & 0.981 & 0.986 & 0.984 \\
\hline
\end{tabular}

Robust standard errors are given in parentheses. The dependent variable is the log number of labor market entrants in a given age group aggregated by gender and at state at entry $\times$ year of entry cells

${ }^{\star} p<0.1 ;{ }^{\star \star} p<0.05 ;{ }^{\star \star \star} p<0.01$ (statistical significance)

and the number of labor market entrants in different age brackets. The estimated regression is as follows:

$$
\ln \left(e_{j t}\right)=\operatorname{ur}_{j t}^{0} \alpha+\psi_{j}+\theta_{t}+\varepsilon_{j t},
$$

with the dependent variable being the log number of labor market entrants in state $j$ and year $t$, and with ur $_{j t}^{0}$ denoting the local unemployment rate in year $t$. We also include state and year fixed effects, denoted by $\psi_{j}$ and $\theta_{t}$, respectively. The first panel of Table 5 suggests that there is a nonnegligible and negative effect of current labor market conditions on the number of entrants aged 16-21. The number of entrants aged 16-21 is estimated to decrease by about $2.8 \%$ for an increase in the local initial unemployment rate by one percentage point. At the same time, the second and third panels of Table 5 show that there is no statistically significant effect on either the number of entrants aged 22-30 or the number of entrants aged 16-30, suggesting that some of the potential entrants with low or medium duration of schooling/training are permanently discouraged from entering the labor market at all, and thus that sample selection over the business cycle occurs through changes at the extensive margin.

Table 6 complements the evidence from Table 5 by looking at the association between the initial local unemployment rate and our two proxies for schooling. Specifically, we regress our proxy for schooling $s_{i}$ on the local initial unemployment rate and additional controls:

$$
s_{i}=\operatorname{ur}_{j[i]}^{0} \alpha+\psi_{j}+\theta_{t}+\varepsilon_{i},
$$

with $\operatorname{ur}_{j[i]}^{0}$ again denoting the local initial unemployment rate, and with $\psi_{j}$ and $\theta_{t}$ denoting fixed effects for state at entry and year of entry, respectively. Based on the results from Table 4, we also include the local unemployment rate at age 16 in some specifications. The results for our first measure of schooling, age at first entry into 
Table 6 Age at first entry into the labor market and age at start of first regular job

\begin{tabular}{|c|c|c|c|c|c|c|c|}
\hline \multirow{3}{*}{$\begin{array}{l}\text { Dependent variable } \\
\text { Mean } \\
\text { Standard deviation }\end{array}$} & \multicolumn{4}{|c|}{ Age at first entry into the labor market } & \multicolumn{3}{|c|}{ Age at start of first regular job } \\
\hline & 18.669 & 18.669 & 18.669 & 18.669 & 19.195 & 19.195 & 19.195 \\
\hline & 1.431 & 1.431 & 1.431 & 1.431 & 1.007 & 1.007 & 1.007 \\
\hline $\operatorname{ur}^{0}$ & $\begin{array}{l}-0.037^{\star \star \star} \\
(0.013)\end{array}$ & $\begin{array}{r}-0.010 \\
(0.009)\end{array}$ & $\begin{array}{r}-0.006 \\
(0.009)\end{array}$ & $\begin{array}{l}0.438^{\star \star \star} \\
(0.032)\end{array}$ & $\begin{array}{r}-0.007 \\
(0.005)\end{array}$ & $\begin{array}{l}0.448^{\star \star \star} \\
(0.034)\end{array}$ & $\begin{array}{l}0.216^{\star \star \star} \\
(0.021)\end{array}$ \\
\hline $\mathrm{ur}^{16}$ & & & & $\begin{array}{l}-0.662^{\star \star \star} \\
(0.028)\end{array}$ & & $\begin{array}{l}-0.679^{\star \star \star} \\
(0.029)\end{array}$ & $\begin{array}{l}-0.328^{\star \star \star} \\
(0.022)\end{array}$ \\
\hline Age at first entry & & & & & & & $\begin{array}{l}0.529^{\star \star \star} \\
(0.020)\end{array}$ \\
\hline State of entry & Yes & Yes & Yes & Yes & Yes & Yes & Yes \\
\hline Year of entry & Yes & Yes & Yes & Yes & Yes & Yes & Yes \\
\hline $\begin{array}{l}\text { Unemployment before } \\
\text { first job }\end{array}$ & No & Yes & Yes & Yes & Yes & Yes & Yes \\
\hline Number of entrants & No & No & Yes & Yes & Yes & Yes & Yes \\
\hline Number of observations & 217,587 & 217,587 & 217,587 & 217,587 & 217,587 & 217,587 & 217,587 \\
\hline Adjusted $R$-squared & 0.043 & 0.267 & 0.267 & 0.397 & 0.057 & 0.333 & 0.674 \\
\hline
\end{tabular}

Robust standard errors are given in parentheses and are clustered by state at entry $\times$ year of entry ${ }^{\star} p<0.1 ;{ }^{\star \star} p<0.05 ;{ }^{\star \star \star} p<0.01$ (statistical significance)

the labor market, yield somewhat mixed results (though the mixed results are probably due to the nature of our schooling proxies). While the first column shows a small positive impact of entry conditions, we get a nonsignificant estimate once we control for individuals' unemployment before their first regular employment. However, once we also include the unemployment rate at age 16, the coefficient on the local unemployment rate at entry turns significantly positive, while the point estimate on the unemployment rate at age 16 is statistically negative (consistent with our discussion of local labor market conditions at age 16 in Section 3.5 above, where we have argued that local labor market conditions are likely to influence both the number and the quality of apprenticeship positions). The second part of Table 6 shows similar results for our second proxy for schooling, age at the start of one's first regular job. Once we control for the unemployment rate at age 16, we get a positive coefficient on the local unemployment rate at entry. Also note, however, that the estimated coefficients imply rather small effects on the average length of schooling/training in any case. $^{22}$

Taken together, the results from Tables 5 and 6 suggest that there is some, arguably positive, sample selection in times of high local unemployment rates. For this reason, we believe that it is plausible to argue that our baseline estimates provide a lower bound on the true effect of labor market entry conditions on wages (or, rather,

\footnotetext{
${ }^{22}$ This result is perhaps not surprising because apprenticeship positions usually have a fixed duration of either 3 or 4 years. Thus, in principle, it may be possible to observe no change in the average length of schooling/training even if there is considerable downranking to lower paying jobs.
} 
the effect of labor market conditions on wages in the absence of any sample selection issues). More importantly, the OLS estimates probably better reflect the overall effects of labor market entry conditions anyway: While OLS estimates reflect both the effect of initial conditions on labor market entry (i.e., sample selection) and wages, IV estimates reflect-ideally (i.e., if the instrument was valid) - the wage effects from initial labor market conditions while eliminating any sample selection issues. That is, in our context, IV estimates approximate a hypothetical or counterfactual scenario in which workers are forced to enter the labor market in recession and firms are forced to offer jobs in recession, respectively. If we are interested in the overall effect of business cycle fluctuations on wages, OLS estimates thus seem to be more informative exactly because they do not net out these compositional effects.

\subsection{Quantitative implications}

Our estimates so far imply a nonnegligible negative long-run wage effect from entering the labor market when the local unemployment rate is high. This is illustrated at the bottom of each table, which, where applicable, shows an approximate estimate of the lifetime loss in wages associated with a hypothetical increase in the initial unemployment rate by one percentage point. The lifetime loss in wages (or any other outcome considered) is computed simply as the average of the accumulated wage losses within the first twenty years of labor market experience.

Our estimates from Tables 2 and 3 imply that an increase in the initial local unemployment rate by one percentage point is associated with an approximate lifetime loss in wages in the range of about 1 to $1.6 \%$, and our preferred specification yields an approximate lifetime loss of $1.3 \%$ for an increase in the local initial unemployment rate by one percentage point. Moreover, according to our argumentation from the preceding section, this likely represents a lower bound (which in turn is consistent with the fact that our 2SLS estimates are larger than our baseline estimates).

Finally, to better understand the true size and economic meaning of these numbers, note that the estimated returns to to apprenticeship training in Austria are on the order of about 3 to $5 \%$ per year (Fersterer et al. 2008). The estimated wage loss resulting from an increase in the local initial unemployment rate by one percentage point thus approximately equals the value of about $0.26-0.4$ a year of apprenticeship training. ${ }^{23}$ This comparison emphasizes that unfavorable labor market entry conditions indeed have a sizable negative effect on workers' lifetime wages.

\section{Initial job assignment}

\subsection{Quality of workers' first employer}

Previous evidence strongly suggests that a worker's first employer may play an important role in explaining not only the immediate, but also the longer-run wage

\footnotetext{
${ }^{23}$ It is reassuring that the estimated coefficient on the proxy for schooling/training equals about 0.046 in our baseline specification (i.e., column 6 of Table 2), which is consistent with the reported external evidence on the returns on apprenticeship training in Austria.
} 
effects resulting from labor market entry conditions (Oreopoulos et al. 2012; von Wachter and Bender 2006). Different mechanisms may explain the observed importance of individuals' initial placement. One important mechanism that may explain cohort effects in wages starts with the observation that there is cyclical variation in job and/or task assignment within jobs over the business cycle and that highly able workers are assigned to jobs with lower-average quality in recessions (e.g., Devereux 2000). ${ }^{24}$ If, moreover, these jobs offer different opportunities for accruing human capital or if, alternatively, a substantial part of human capital accumulated on the job is specific to a worker's task, occupation, and/or industry, then initial job and/or task assignment is probably able to explain a significant part of the observed persistent wage effects resulting from unfavorable initial labor market conditions (e.g., Gibbons 2006). ${ }^{25}$ A similar argument is put forth in a more recent study by Liu et al. (2012), who argue that cyclical skill mismatch can generate persistent wage effects if at least part of the human capital acquired in a worker's first job/task is nontransferable to subsequent jobs/tasks and assuming that previously acquired (and potentially superior) human capital depreciates while not put to use.

Inspired by this evidence, we also provide an analysis of the association of initial labor market conditions and the quality of a worker's first job, which we complement with evidence on search frictions. We use a variety of different measures of the quality of workers' first employment. The first two measures are firm-level compensation measures, but we also look at a firm's size and age and the possibility that it might "disappear" within the following year or the following 4 years. ${ }^{26}$ We regress each of these measures on the initial local unemployment rate and a couple of additional control variables:

$$
\begin{gathered}
\omega_{i}^{k\left(t_{0}\right)}=\operatorname{ur}_{j[i]}^{0} \alpha+\psi_{i}^{j\left(t_{0}\right)}+\phi_{i}^{t_{0}}+x_{i}^{0} \beta_{1}+\ln \left(n_{j[i]}^{0}\right) \beta_{2}+\epsilon_{i}, \quad \text { or } \\
\omega_{i}^{k\left(t_{0}\right)}=\operatorname{ur}_{j[i]}^{0} \alpha+\psi_{i}^{j\left(t_{0}\right)}+\phi_{i}^{t_{0}}+x_{i}^{0} \beta_{1}+\ln \left(n_{j[i]}^{0}\right) \beta_{2}+\lambda_{i}^{k\left(t_{0}\right)}+\epsilon_{i},
\end{gathered}
$$

where $\omega_{i}^{k\left(t_{0}\right)}$ denotes some outcome for individual $i$ who first enters the labor market in year $t_{0}$ at employer $k$. The local initial unemployment rate $\operatorname{ur}_{j[i]}^{0}$ is again the regressor of main interest. We also include the same set of individual-level controls $x_{i}^{0}$, the log number of labor market entrants $n_{j[i]}^{0}$, as well as a full set of dummy variables indicating the state a worker resides in at entry, $\psi_{i}^{j\left(t_{0}\right)}$, and year of entry, $\phi_{i}^{t_{0}}$. As the above, standard errors are clustered by year at entry $\times$ state at entry. We show results with and without controls for an employer's industry affiliation $\lambda_{i}^{k\left(t_{0}\right)}$ because

\footnotetext{
${ }^{24}$ In line with these findings, Mansour (2009) finds that the quality of a worker's first job is lower when entry happens during high unemployment, even though cohorts entering during recession are positively selected.

${ }^{25}$ See Gathmann and Schönberg (2010) for evidence on task-specific, Kambourov and Manovskii (2009) on occupation-specific, and Neal (1995) or Parent (2000) on industry-specific human capital. Sullivan (2010) provides evidence that both occupation- and industry-specific human capital are decisive in determining the level of wages.

${ }^{26}$ The "disappearance" of a firm identifier does not necessarily coincide with a plant closure because a firm identifier may also disappear for other reasons (e.g., because of a take-over by another firm).
} 
of potential endogeneity. Estimates of $\alpha$ are shown in Table 7; estimates without industry controls and estimates including industry controls are shown.

Consistent with previous evidence, we find considerable cyclical variation in most of our performance measures for workers' initial employer. Not surprisingly, the first two columns of Table 7 show that entry in times of high local unemployment is associated with starting one's labor market career with an employer who pays considerably lower compensation on average. Initial employers of workers entering at different labor market conditions also differ in other dimensions, however. Specifically, columns 3-6 show that workers entering during times of high local unemployment also tend to enter the labor market through firms that are younger and smaller than first employers of workers who enter the labor force when the labor market is tight. More remarkably, the final two columns show that those individuals entering when unemployment is high are also much more likely to end up with an employer who is doomed to fail in the near future.

The comparison between the two panels of Table 7 further suggests that some of the downgrading during bad entry conditions occurs both across and within industries. For example, the first two columns show that the estimated coefficients on wages and earnings are smaller if we control for industry affiliation of workers' initial employers, implying that part of the negative effect on wages/earnings stems from the fact that workers are more likely to start working with an employer from an industry that offers lower compensation.

Because we neither have direct nor detailed measures of the schooling and training actually acquired, we cannot provide any direct assessment on the importance of skill mismatch as that by Liu et al. (2012). We can, however, provide some direct evidence on the cyclicality of search frictions (which seems to be a natural precondition for skill mismatch). Table 8 shows that workers who enter during high unemployment not only end up working at a firm that is economically weaker, but that they also have a more difficult time of finding an employer at all. Specifically, the first three columns show that a higher local initial unemployment rate is associated with an increased likelihood of experiencing an unemployment spell before starting regular employment, with longer unemployment, as well as an increased probability of experiencing long-term unemployment even before starting one's first regular employment spell. Finally, the fourth column shows that workers entering during an economic downturn are also more likely to start their labor market career through marginal (i.e., poorly paid) employment.

\subsection{The importance of the initial employer for the evolution of wages}

Given this pronounced effects of initial conditions on various quality measures of workers' first employer, we next focus on the importance of workers' first employer on the evolution of their starting as well as subsequent wages. To this end, we simply augment our baseline model, i.e., Eq. 2, with additional controls for a worker's first employer in a first step.

The first column of Table 9 again replicates our baseline estimates, without any controls for an individual's initial employer. In contrast, the specification in the second column shows estimates from a regression that includes fixed effects for a 


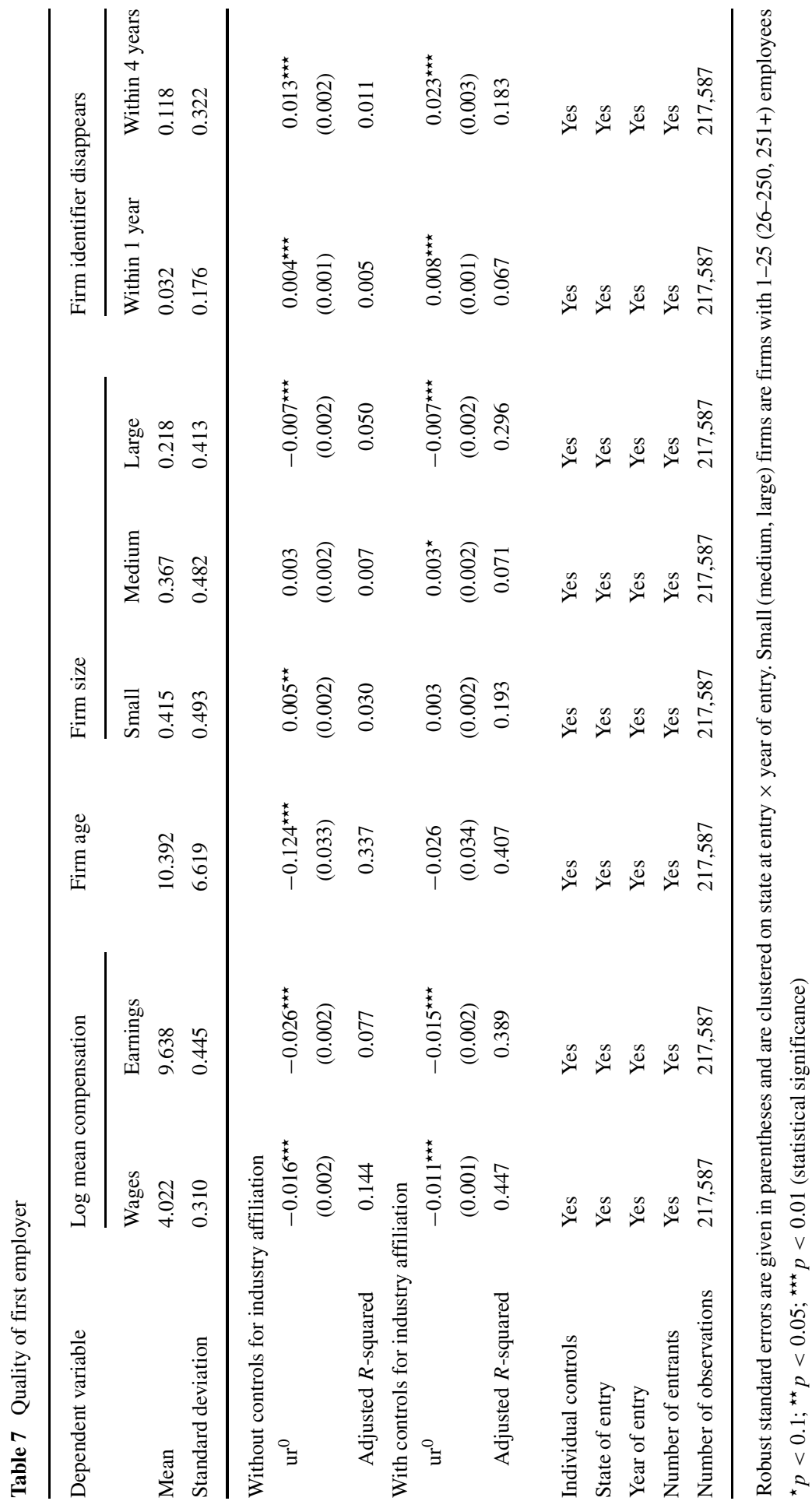




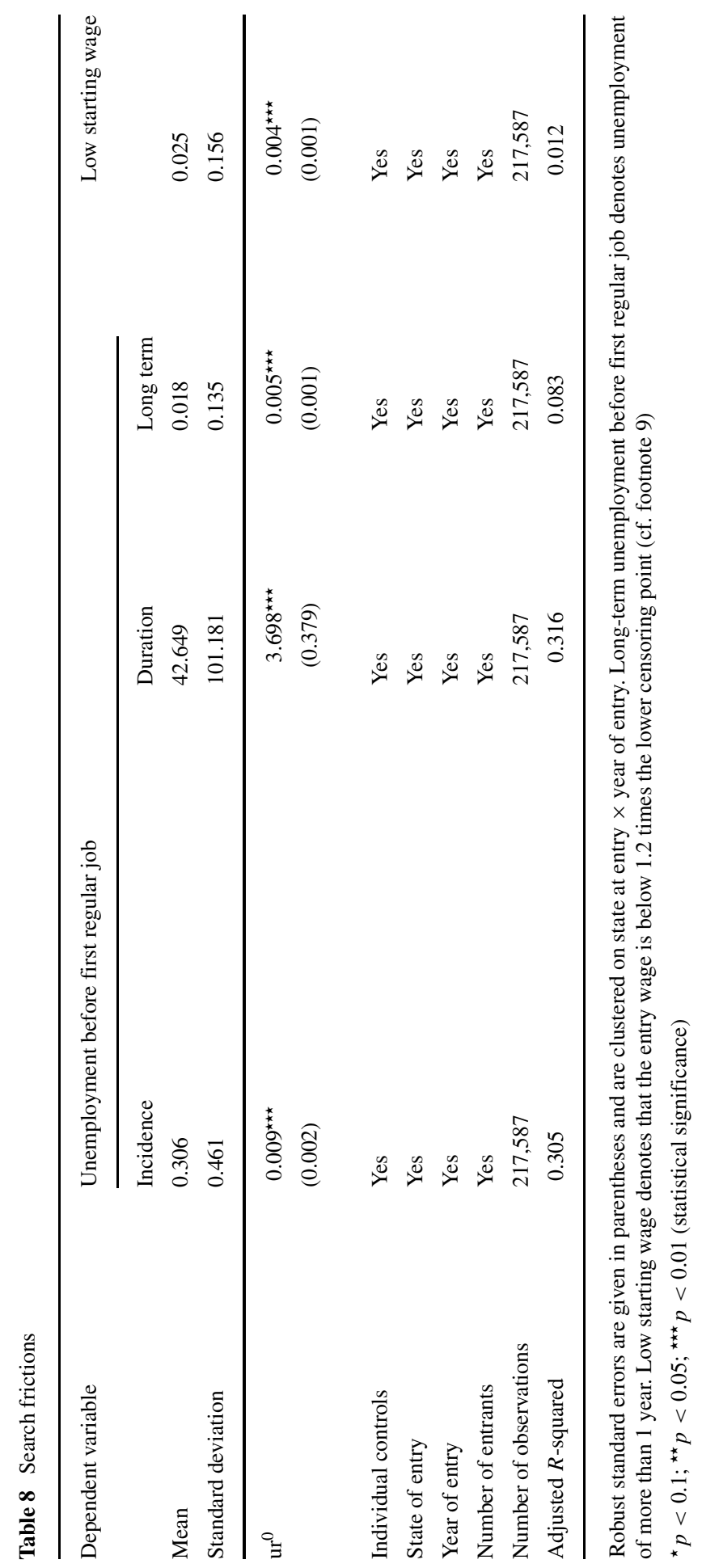




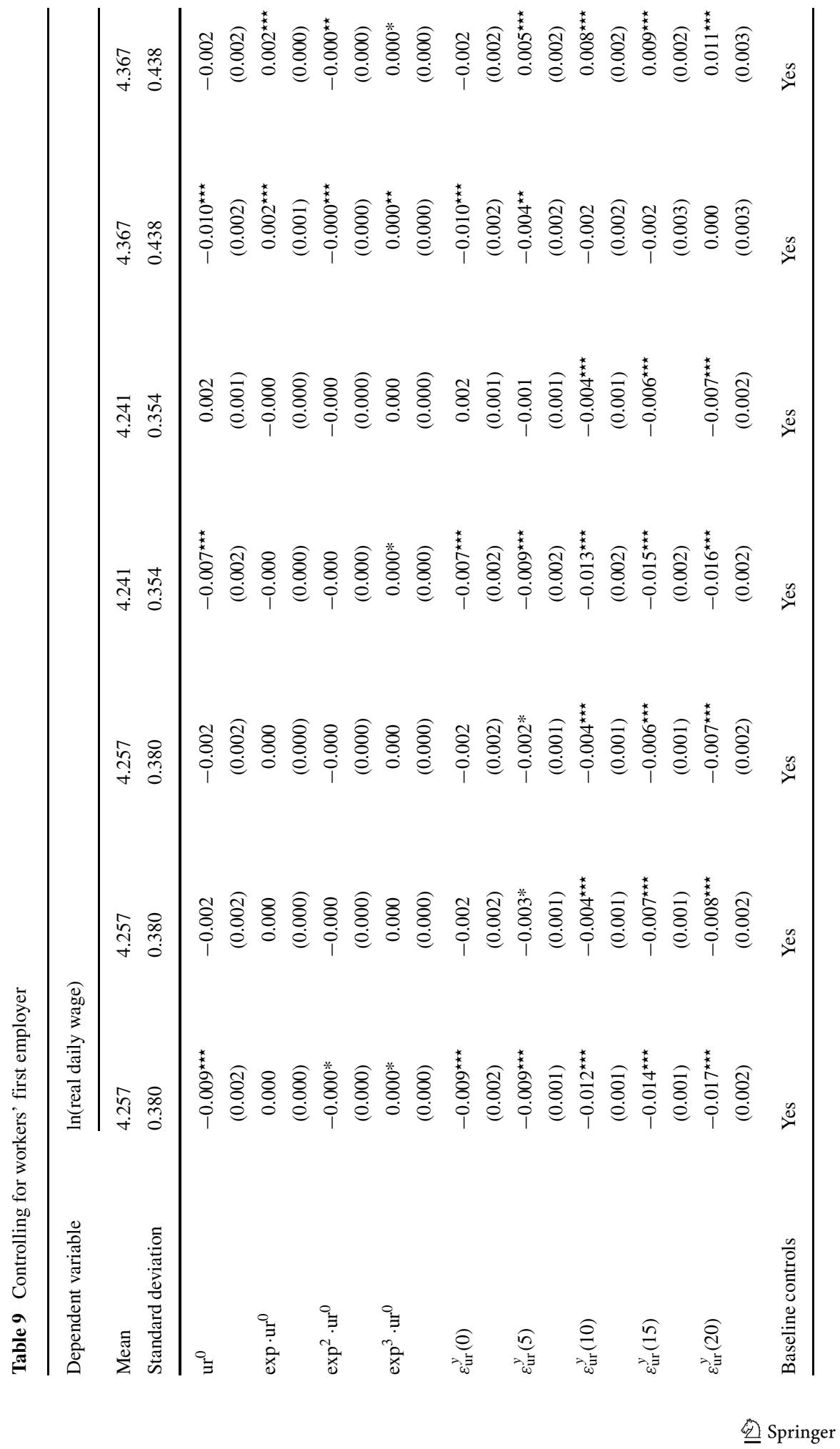




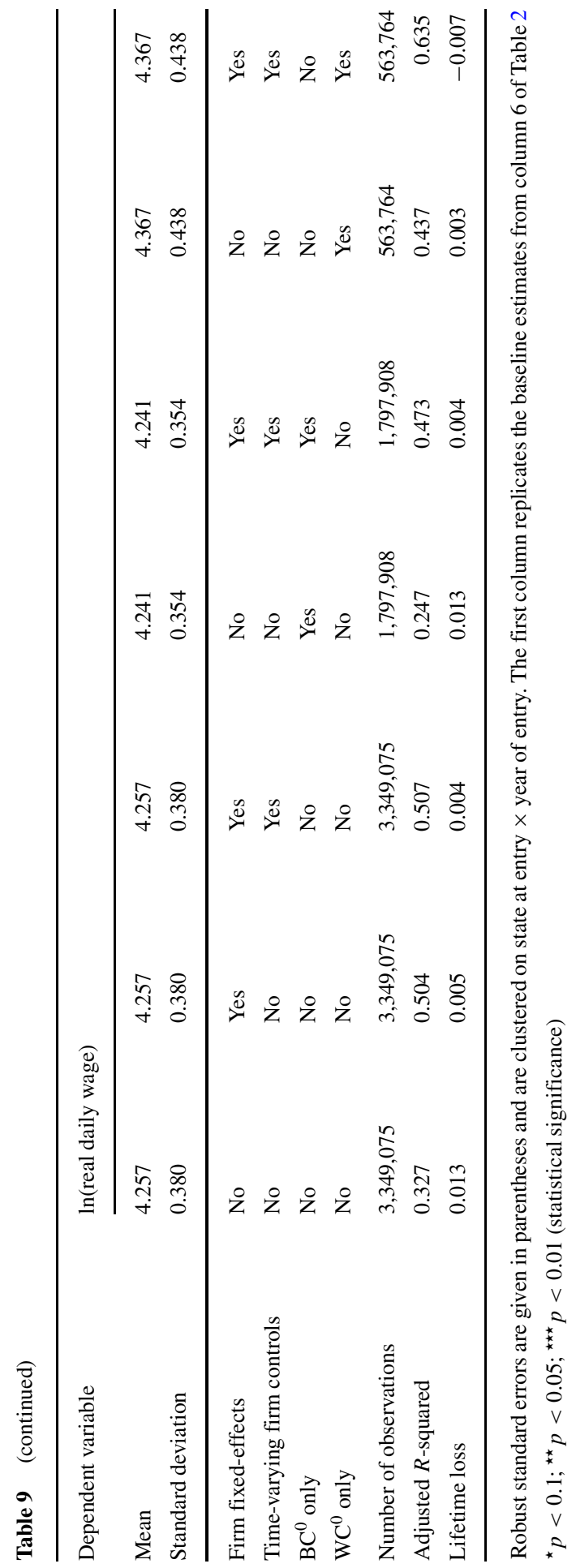


worker's initial employer and thus controls for all time-invariant employer characteristics (whether observed or not). ${ }^{27}$ Estimates turn out to be markedly different from those of our baseline specification. First, the estimated wage effect in the year of entry is much smaller than in the baseline specification ( -0.002 compared to -0.009$)$, and moreover, the estimate is no longer statistically significant. Thus controlling for workers' initial employer seems to pick up not only all of the short run but also most of the long-run wage effect from poor entry conditions. Indeed, while the lifetime loss in wages amounts to about $1.3 \%$ in our baseline specification, controlling for both observed and unobserved characteristics of the first employer only yields an estimate of about $0.4 \%$. Thus, similar to that of Oreopoulos et al. (2012), controlling for the characteristics of workers' first employer explains most of the observed wage effects.

To explore the remaining negative wage effect in the longer run in somewhat more detail, we next split the sample by initial occupation (i.e., blue-collar versus white-collar occupations). ${ }^{28}$ Columns 4 and 6 show results for blue-collar and white-collar workers separately without controls for the initial employer, while columns 5 and 7 show results with these controls. This shows that there are remarkably distinct results by initial occupation. Specifically, even though the initial wage effect is statistically similar for blue- and white-collar workers, the longer-run effect differs substantially between the two groups. Specifically, because there is much less persistence in wage losses from poor entry conditions, the long-run wage effects for white-collar workers are only about one-quarter the size of those for blue-collar workers (our estimates imply an approximate loss in lifetime wages of only $0.3 \%$ for white-collar workers, compared to about $1.3 \%$ for blue-collar workers). ${ }^{29}$ This result may emphasize that initial job and/or task assignment and occupation-specific human capital are important in explaining persistent wage effects especially because occupation-specific human capital is arguably more important for blue- (e.g., craftsmen) than for white-collar jobs (e.g., Sullivan 2010). ${ }^{30}$

\footnotetext{
${ }^{27}$ We further include controls for time-varying characteristics of initial employers in column 3 , but these variables do not have much additional impact on the estimated wage effects on top of the fixed effects for first employer.

${ }^{28}$ Note that these two groups do not exactly add up to the overall sample size because some employment spells cannot be uniquely identified as either blue or white collar (cf. Table 1).

${ }^{29}$ This result is somewhat surprising because previous research has shown that white-collar workers in Austria suffer from much larger and more persistent wage losses from job displacement (Schwerdt et al. 2010). However, we use a totally different sample of workers than that of Schwerdt et al. (2010). Moreover, our study focuses on low- and medium-skilled labor market entrants who entered the labor force between 1978 and 2000, while Schwerdt et al. (2010) focus on prime age workers of any educational level who experienced a plant closure between 1982 and 1988.

${ }^{30}$ We provide some additional evidence that appears to be consistent and complementary with this explanation in the Electronic Supplementary Material (ESM). These additional results show that the adjustment in employer quality is incomplete for blue-collar workers, notwithstanding an increase in job mobility in at least the first 5 years of their labor market career, and that there is a permanent increase in the risk of job displacement. These findings suggest that some blue-collar workers entering the labor force in an economic downturn are forced into, and persistently locked in, low-paying jobs and/or tasks.
} 


\section{Conclusions}

We estimate the long-run impact of initial labor market conditions on wages for young males entering the Austrian labor market between 1978 and 2000. Consistent with previous evidence, we find a substantial wage penalty from poor entry conditions on starting wages. The estimated semi-elasticity of starting wages with respect to the initial unemployment rate is on the order of -0.005 to -0.010 , with our preferred estimate equaling -0.009 (implying that a one percentage point increase in the initial local unemployment rate is associated with $0.9 \%$ lower starting wages). Moreover, this initial wage loss from first entry into the labor force during high local unemployment turns out to be highly persistent. Consequently, we find sizable negative effects on lifetime wages. Our preferred estimates imply that an increase in the initial local unemployment rate by one percentage point is associated with an approximate loss in lifetime wages of about $1.3 \%$. Moreover, our estimates are close to the results reported by Stevens (2007) for Germany and by Kwon et al. (2010) for Sweden. Our finding of persistent wage effects from poor entry conditions is also in line with those of Frühwirth-Schnatter et al. (2011) who study on labor earning mobility in Austria by using the same data source as we do, but a completely different empirical approach.

We further show that there is considerable cyclical variation in the quality of a worker's first regular employment. Even though workers are positively selected in times of high unemployment, they often end up working with employers that generally pay lower wages. We also show that initial job and/or task assignment within jobs is very important in explaining both the short- and long-run wage effects from entry into the labor force during poor local entry conditions. In fact, controlling for the characteristics of workers' first employers can explain as much as three-quarters of the observed long-run wage effects resulting from poor entry conditions.

We finally find some very distinct patterns for blue and white-collar workers. The negative wage effects fade away for white-collar workers after about 5 to 10 years, while blue-collar workers suffer from very persistent negative wage effects from poor labor market entry conditions. At least part of this difference appears to be related to corresponding differences in the speed of quality adjustment of subsequent employers between occupations, where only blue-collar workers are permanently downgraded to lower-quality employers.

Acknowledgments We thank two anonymous referees, Joshua Angrist, Johann Brunner, Pierre Cahuc, Christian Dustmann, Marcus Hagedorn, Martin Halla, Christian Hepenstrick, Helmut Hofer, Steinar Holden, Bo Honoré, Rafael Lalive, Michael Lechner, Andrew Oswald, Tamas Papp, Michael Reiter, Steven Stillman, Petra Todd, Till von Wachter, Rudolf Winter-Ebmer, Andrea Weber, Tobias Würgler, Josef Zweimüller, seminar participants in Engelberg, Linz, Vienna, Weggis, and Zurich, as well as participants at the 2009 Spring Meeting of Young Economists in Istanbul, the 15th International Conference on Panel Data in Bonn, and the 13th IZA European Summer School in Labor Economics in Buch/Ammersee for helpful comments and suggestions at various stages of this project. Financial support by the Austrian Science Fund is gratefully acknowledged ("The Austrian Center for Labor Economics and the Analysis of the Welfare State"). 


\section{Appendix A: Sample construction}

We first determine the start of the first regular employment spell for each male individual born between 1958 and $1985 .{ }^{31}$ The restriction with respect to year of birth, in combination with the restriction on age at beginning of one's first regular job that we apply below, ensures that the potential range of age at first entry into the labor force is the same for each entry cohort considered in the analysis (1978-2000). Additionally, we drop all individuals who were self-employed and/or worked as a farmer or civil servant at least once, because the data do not consistently cover these employment spells over the whole period of analysis and/or because earnings are not recorded (in the case of self-employment). We thus cannot fully observe the employment and/or earnings histories of such individuals.

We then determine each individual's age at the start of his first regular employment spell starting between 1978 and 2000. We define regular employment as an employment spell which lasts for at least 180 days. ${ }^{32}$ We also focus on individuals aged between 16 and 21 years at the start of their first regular employment spell. This leaves us with 797,846 unique individuals (see Table 10), from which we take a simple $30 \%$ random sample. This finally yields a total of 217,587 unique individuals and 3,349,075 observations (= individuals $\times$ years) when following these individuals over time.

Table 10 shows descriptive statistics for some key variables, by individuals' age at the time of first entry into the labor force. We consistently exclude individuals who start their first regular employment after they attain age 30 because they presumably never enter the labor force at all. ${ }^{33}$ The first column of Table 10 shows descriptives for all individuals, and the second (third) column shows descriptives for individuals aged 16 to 21 (aged 22 to 30 ) when starting their first employment. A comparison of the second to the third columns shows that our sample restriction with respect to age at the start of first regular employment works as expected. The sample of lowerskilled workers, compared to the group of higher-skilled workers, contains a higher fraction of blue-collar workers and has considerably lower wages on average and shorter duration of the first regular employment spell.

Also note that, for the group of individuals aged between 22 and 30 when first entering the labor force, highly skilled workers potentially are mixed up with lowly

\footnotetext{
${ }^{31}$ Obviously, an individual must be covered by the ASSD in order to be included in the sample. An individual is covered by the ASSD if he or she is entitled to future social security benefits (typically old-age benefits) or has already claimed social security benefits before first entering the labor force. Typically, individuals "enter" the ASSD once they start working.

${ }^{32}$ Importantly, vocational training such as apprenticeship training is not considered as regular employment (but as formal training).

${ }^{33}$ The group of individuals who enter at a later age probably consists of two very different groups, who are indistinguishable from each other in the data. On the one hand, there are truly high-skilled workers who enter the labor market at a later stage because they continued their education until that time. On the other hand, however, there are also low-skilled workers who were never employed or only sporadically employed before starting their first regular employment. Because schooling is not directly observed, we would mix these two groups of workers together if we were to include them.
} 
skilled workers: individuals in this group of workers either spent much time in education, were previously unemployed, or had short employment spells not counting as regular employment. This is apparent from the proportion of workers below the lower censoring point or above the higher censoring point. The probability of crossing any of the two points is higher for the sample of older workers. Consequently, the variation in the real daily wage (and thus productivity) is considerably smaller in the sample of younger workers than in the group of older workers.

Table 10 Sample selection

\begin{tabular}{|c|c|c|c|c|c|c|}
\hline & \multicolumn{6}{|c|}{ Age at start of first regular employment } \\
\hline & $16-30$ & & $16-21$ & & $22-30$ & \\
\hline Real daily wage & 50.488 & (18.644) & 47.536 & $(15.303)$ & 56.742 & $(23.027)$ \\
\hline Age at start of first job & 20.863 & $(2.948)$ & 19.200 & $(1.004)$ & 24.386 & $(2.589)$ \\
\hline Duration of first regular job & 2.800 & $(3.995)$ & 2.692 & $(4.035)$ & 3.030 & $(3.900)$ \\
\hline Blue collar & 0.650 & $(0.477)$ & 0.726 & $(0.446)$ & 0.487 & $(0.500)$ \\
\hline White collar & 0.348 & $(0.476)$ & 0.271 & $(0.445)$ & 0.510 & $(0.500)$ \\
\hline Below GfGr: yes = 1 & 0.059 & $(0.235)$ & 0.050 & $(0.219)$ & 0.077 & $(0.266)$ \\
\hline Above HBGr: yes = 1 & 0.049 & $(0.215)$ & 0.019 & $(0.135)$ & 0.112 & $(0.315)$ \\
\hline \multicolumn{7}{|l|}{ Region of employer } \\
\hline Vienna & 0.239 & $(0.426)$ & 0.198 & $(0.398)$ & 0.326 & $(0.469)$ \\
\hline Lower Austria & 0.158 & $(0.365)$ & 0.171 & $(0.377)$ & 0.129 & $(0.336)$ \\
\hline Burgenland & 0.024 & $(0.152)$ & 0.000 & $(0.000)$ & 0.021 & $(0.142)$ \\
\hline Upper Austria & 0.168 & $(0.374)$ & 0.183 & $(0.387)$ & 0.137 & $(0.344)$ \\
\hline Styria & 0.139 & $(0.346)$ & 0.145 & $(0.352)$ & 0.129 & $(0.335)$ \\
\hline Carinthia & 0.065 & $(0.246)$ & 0.066 & $(0.249)$ & 0.062 & $(0.241)$ \\
\hline Salzburg & 0.070 & $(0.255)$ & 0.071 & $(0.257)$ & 0.067 & $(0.249)$ \\
\hline Tyrol & 0.090 & $(0.286)$ & 0.091 & $(0.288)$ & 0.087 & $(0.282)$ \\
\hline Vorarlberg & 0.000 & $(0.000)$ & 0.049 & $(0.217)$ & 0.000 & $(0.000)$ \\
\hline \multicolumn{7}{|l|}{ Industry of employer } \\
\hline Agriculture & 0.015 & $(0.120)$ & 0.012 & $(0.108)$ & 0.021 & $(0.142)$ \\
\hline Electricity & 0.007 & $(0.085)$ & 0.009 & $(0.095)$ & 0.003 & $(0.057)$ \\
\hline Mining & 0.006 & $(0.078)$ & 0.007 & $(0.082)$ & 0.005 & $(0.068)$ \\
\hline Manufacturing & 0.344 & $(0.475)$ & 0.401 & $(0.490)$ & 0.225 & $(0.417)$ \\
\hline Construction & 0.165 & $(0.371)$ & 0.190 & $(0.392)$ & 0.114 & $(0.318)$ \\
\hline Wholesale and retail trade & 0.150 & $(0.357)$ & 0.159 & $(0.366)$ & 0.130 & $(0.336)$ \\
\hline Gastronomy, hotel business & 0.060 & $(0.237)$ & 0.046 & $(0.209)$ & 0.089 & $(0.285)$ \\
\hline Transportation & 0.059 & $(0.236)$ & 0.060 & $(0.238)$ & 0.057 & $(0.233)$ \\
\hline Finance & 0.082 & $(0.274)$ & 0.058 & $(0.235)$ & 0.130 & $(0.337)$ \\
\hline Cleaning, body care & 0.009 & $(0.096)$ & 0.008 & $(0.089)$ & 0.012 & $(0.109)$ \\
\hline Arts, entertainment, sports & 0.010 & $(0.102)$ & 0.005 & $(0.072)$ & 0.021 & $(0.145)$ \\
\hline
\end{tabular}


Table 10 (continued)

\begin{tabular}{lllllll}
\hline & \multicolumn{7}{l}{ Age at start of first regular employment } \\
\cline { 2 - 7 } & $16-30$ & & $16-21$ & & $22-30$ \\
\hline Healthcare, welfare & 0.014 & $(0.116)$ & 0.006 & $(0.079)$ & 0.029 & $(0.167)$ \\
Education, research & 0.015 & $(0.121)$ & 0.000 & $(0.000)$ & 0.037 & $(0.189)$ \\
Lobbies, social security agencies & 0.063 & $(0.243)$ & 0.033 & $(0.180)$ & 0.125 & $(0.331)$ \\
Housekeeping & 0.000 & $(0.000)$ & 0.000 & $(0.022)$ & 0.000 & $(0.000)$ \\
Number of observations & $1,174,523$ & & 797,846 & & 376,677 & \\
\hline
\end{tabular}

Table entries are sample means and standard deviations (in parentheses). Daily wages are given in Euros. Real wage are deflated using the consumer price index with base year 2007. GfGr ("Gerinfügigkeitsgrenze") and HBGr ("Höchstbemessungsgrundlage") denote the upper and the lower censoring point with respect to earnings, respectively. "Below GfGr" is an indicator taking on the value 1 if the nominal daily wage is equal to or below 1.2 times the lower censoring point and 0 otherwise. "Above HBGr" is an indicator taking on the value 1 if the nominal daily wage is equal to or above 0.8 times the upper censoring point and 0 otherwise

\section{References}

Angrist J, Krueger A (1994) Why do World War II veterans earn more than nonveterans? J Labor Econ 12(1):74-97

Bils MJ (1985) Real wages over the business cycle: evidence from panel data. Polit Econ 93(4):666-689

Blanchflower DG, Oswald AJ (1990) The wage curve. Scand J Econ 92(2):215-235

Blundell R, Reed H, Stoker TM (2003) Interpreting aggregate wage growth: the role of labor market participation. Am Econ Rev 93(4):1114-1131

Burgess S, Propper C, Rees H, Shearer A (2003) The class of 1981: the effects of early career unemployment on subsequent unemployment experiences. Labour Econ 10(3):291-309

Clark D (2011) Do recessions keep students in school? The impact of youth unemployment on enrolment in post-compulsory education in England. Economica 78(311):523-545

Devereux PJ (2000) Task assignment over the business cycle. J Labor Econ 18(1):98-124

Elsby MW, Hobijn B, Şahin A (2010) The labor market in the great recession. Brookings Pap Eco Ac 2010(1): $1-48$

Federal Ministry for Education, the Arts and Culture (2008) Development of Education in Austria, 20042007. Federal Ministry for Education, the Arts and Culture, Vienna

Fersterer J, Pischke J, Winter-Ebmer R (2008) Returns to apprenticeship training in Austria: evidence from failed firms. Scand J Econ 110(4):733-753

Frühwirth-Schnatter S, Pamminger C, Weber A, Winter-Ebmer R (2011) Labor market entry and earnings dynamics: Bayesian inference using mixtures-of-experts Markov chain clustering. J Appl Econom 27(7):1116-1137

Gardecki R, Neumark D (1998) Order from chaos? The effects of early labor market experiences on adult labor market outcomes. Ind Labor Relat Rev 51(2):299-322

Gathmann C, Schönberg U (2010) How general is human capital? A task-based approach. J Labor Econ 28(1): $1-49$

Genda Y, Kondo A, Ohta S (2010) Long-term effects of a recession at labor market entry in Japan and the United States. J Hum Resour 45(1):157-196

Gibbons R, Waldman M (2006) Enriching a theory of wage and promotion dynamics inside firms. J Labor Econ 24(1):59-107

Giuliano P, Spilimbergo A (2009) Growing up in a recession. NBER working paper no. 15321. NBER, Cambridge

Kahn LB (2010) The long-term labor market consequences of graduating from college in a bad economy. Labour Econ 17(2):303-316 
Kambourov G, Manovskii I (2009) Occupational specificity of human capital. Int Econ Rev 50(1):63-115

Kondo A (2008) Differential effects of graduating during a recession across race and gender. Columbia University, New York. Mimeo

Kondo A (2012) Gender-specific labor market conditions and family formation. J Popul Econ 25(1):151174

Kwon I, Milgrom Meyersson EM, Hwang S (2010) Cohort effects in promotions and wages. Evidence from Sweden and the United States. J Hum Resour 45(3):772-808

Liu K, Salvanes KG, Sørensen EØ (2012) Good skills in bad times: cyclical skill mismatch and the longterm effects of graduating in a recession. IZA discussion paper 6820. IZA, Bonn

Mansour H (2009) The career effects of graduating from college in a bad economy: the role of workers' ability. University of Colorado Denver, Denver. Mimeo

Moulton BR (1986) Random group effects and the precision of regression estimates. J Econometrics 32(3):385-397

Muehlemann S, Wolter SC, Wuest A (2009) Apprenticeship training and the business cycle. Empirical Res Vocat Educ Train 1(2):173-186

Murphy KM, Welch F (1990) Empirical age-earnings profiles. J Labor Econ 8(2):202-229

Neal D (1995) Industry-specific human capital: evidence from displaced workers. J Labor Econ 13(4):653677

Neumark D (2002) Youth labor markets in the United States: shopping around vs staying put. Rev Econ Stat 84(3):462-482

Nijkamp P, Poot J (2005) The last word on the wage curve? J Econ Surv 19(3):421-450

Oreopoulos P, von Wachter T, Heisz A (2012) The short- and long-term career effects of graduating in a recession. Am Econ J Appl Econ 4(1):1-29

Oyer P (2006) Initial labor market conditions and long-term outcomes for economists. J Econ Perspect 20(3):143-160

Oyer P (2008) The making of an investment banker: stock market shocks, career choice, and lifetime income. J Financ 63(6):2601-2628

Parent D (2000) Industry-specific capital and the wage profile: evidence from the national longitudinal survey of youth and the panel study of income dynamics. J Labor Econ 18(2):306-323

Raaum O, Røed K (2006) Do business cycle conditions at the time of labor market entry affect future employment prospects? Rev Econ Stat 88(2):193-210

Schwerdt G, Ichino A, Ruf O, Winter-Ebmer R, Zweimüller J (2010) Does the color of the collar matter? Employment and earnings after plant closure. Econ Lett 108(2):137-140

Solon G, Barsky R, Parker JA (1994) Measuring the cyclicality of real wages: how important is composition bias? Q J Econ 109(1):1-25

Stevens K (2007) Adverse economic conditions at labour market entry: permanent scars or rapid catch-up? University College London, London. Mimeo

Sullivan P (2010) Empirical evidence on occupation and industry specific human capital. Labour Econ 17(3):567-580

Topel RH, Ward MP (1992) Job mobility and the careers of young men. Q J Econ 107(2):439-479

von Wachter T, Bender S (2008) Do initial conditions persist between firms? An analysis of firm-entry cohort effects and job losers using matched employer-employee data. In: Bender S, Lane J, Shaw KL, Andersson F, von Wachter T (eds) The analysis of firms and employees. Quantitative and qualitative approaches. National Bureau of Economic Research, Cambridge, pp 135-162

von Wachter T, Bender S (2006) In the right place at the wrong time: the role of firms and luck in young workers' careers. Am Econ Rev 96(5):1679-1705

Wozniak A (2010) Are college graduates more responsive to distant labor market opportunities? J Hum Resour 45(4):944-970

Zweimüller J, Winter-Ebmer R, Lalive R, Kuhn A, Ruf O, Wuellrich JP, Büchi S (2009) The Austrian social security database (ASSD). NRN: the Austrian center for labor economics and the analysis of the welfare state. Working paper 0903. NRN, Linz 